\title{
A multiarm randomized field trial evaluating strategies for udder health improvement in Swiss dairy herds
}

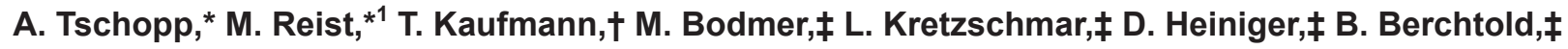 \\ F. Wohlfender, ${ }^{*}$ M. Harisberger, ${ }^{*}$ R. Boss,§ D. Strabel, $†$ M.-E. Cousin,\# H. U. Graber,§ A. Steiner,‡ \\ and B. H. P. van den Borne ${ }^{\star 2}$ \\ *Veterinary Public Health Institute, Vetsuisse Faculty, University of Bern, 3097 Liebefeld, Switzerland \\ †Bovine Health Service, AGRIDEA, 8315 Lindau, Switzerland \\ $\ddagger$ Clinic for Ruminants, Vetsuisse Faculty, University of Bern, 3012 Bern, Switzerland \\ §Agroscope Liebefeld-Posieux Research Station ALP, 3003 Bern, Switzerland \\ \#Consumer Behavior, Institute for Environmental Decisions (IED), ETH Zürich, 8092 Zürich, Switzerland
}

\begin{abstract}
The aims of this study were to quantify the effectiveness of specialist advice about udder health in Swiss dairy herds and to compare 3 different udder health improvement strategies against a negative control group. In 2010, 100 Swiss dairy herds with a high (between 200,000 and 300,000 cells $/ \mathrm{mL}$ ) yield-corrected bulk milk somatic cell count (YCBMSCC) were recruited for a 1-yr multiarm randomized field trial. The herds were visited between September and December 2011 to evaluate udder health-management practices and then randomly allocated into 1 of 4 study arms containing 25 herds each. The negative control study arm received neither recommendations for improving udder health nor any active support. The remaining 75 farmers received a herd-specific report with recommendations to improve udder health management. The positive control study arm received no further active support during 2012. The veterinarian study arm received additional support in the form of monthly visits by their herd veterinarian. Finally, the study group study arm received support in the form of bimonthly study group meetings where different topics concerning udder health were discussed. One year later, implementation of recommendations and changes in udder health were assessed. Of the recommendations given, $44.3 \%$ were completely implemented, $23.1 \%$ partially, and $32.6 \%$ were not implemented. No differences in implementation of recommendations were noted between the 3 study arms. At study enrollment, farmers were asked for the study arm of their preference but were subsequently randomly assigned to 1 of the 4 study arms.
\end{abstract}

Received February 14, 2014.

Accepted September 30, 2014.

${ }^{1}$ Current address: Swiss Federal Food Safety and Veterinary Office, 3097 Liebefeld, Switzerland.

${ }^{2}$ Corresponding author: bart.vandenborne@vetsuisse.unibe.ch
Farmers that were assigned to the study arm of their preference implemented more recommendations than farmers assigned to a study arm not of their preference. No decrease in the within-herd prevalence of cows that had a high $(\geq 200,000$ cells $/ \mathrm{mL})$ composite somatic cell count was observed in herds that had a YCBMSCC $\geq 200,000$ cells/mL at the start of intervention. However, the 3 study arms with intervention (positive control, the veterinarian, and the study groups) prevented an increase in the within-herd prevalence of cows that had a high somatic cell count in herds with a low YCBMSCC at the start of the intervention compared with the negative control study arm. In the year after sending the report, herds assigned to the study group study arm had a reduced incidence rate of treated mastitis cases in comparison with the year before sending the report. Key words: mastitis, herd health management, peer support, intervention

\section{INTRODUCTION}

Mastitis is defined as the inflammation of the mammary gland and is the most frequent and costly disease in the dairy industry (Halasa et al., 2007; Hogeveen et al., 2011). Mastitis is a multifactorial disease (Harmon, 1994) for which many risk factors have been identified. These include management practices such as milking hygiene, milking technique, housing, general herd health management, and individual cow factors (e.g., Barkema et al., 1999; Breen et al., 2009; Dufour et al., 2011). Distributions of mastitis-causing pathogens and implementation of preventive management practices differ considerably among dairy herds, and a herd-specific approach is needed to ensure that improvements made are sustainable (Lam et al., 2013).

The greatest improvement in udder health can be expected when as many beneficial management practices as possible are implemented. In a UK intervention study (Green et al., 2007), similar to the one reported 
here, data about mastitis management and herd environment were collected during herd visits. Herd-specific recommendations were subsequently given to farmers to optimize mastitis management. After $1 \mathrm{yr}$, the proportion of cows affected with clinical mastitis and the number of cows with new SCC elevations were both reduced by $22 \%$ (Green et al., 2007). This strategy is now being rolled out in a nationwide mastitis-control program in the United Kingdom. However, herds were only visited to assess the mastitis management in the current study. No further support was given to farmers, even though continued knowledge transfer is assumed to improve farmer compliance with respect to implementing management changes and sustainably improving the herd's overall health status (Main et al., 2012; Lam et al., 2013).

Generally, farmers see their veterinarian as the first source of knowledge for dealing with udder health problems (Jansen et al., 2009; Lam et al., 2011; Pothmann et al., 2014). However, farmers rarely ask their veterinarian for advice if they do not think that they have a mastitis problem (Lam et al., 2011). Farmers should be made aware of potential problems and improvements should be implemented before serious udder and herd health problems arise. Veterinary herd health management is becoming increasingly important, and modern veterinarians need to be knowledgeable advice-oriented consultants who provide evidence-based preventive advice (LeBlanc et al., 2006; Lam et al., 2011). The quality of the advice and the relationship with the farmer plays an important role in the level of farmer compliance with veterinary recommendations (Sorge et al., 2010). A trusting relationship between a proactive veterinarian and a farmer is assumed to be effective for animal health improvement (Derks et al., 2012).

Bringing dairy farmers together and letting them share and discuss their udder health experiences in peer study groups is another udder health-improvement strategy. Farmers may be more willing to accept knowledge from peers than from their private veterinarians (Vaarst et al., 2007; Lam et al., 2011) and this might contribute to their willingness to improve the mastitis management in their herds. Peer study groups have been shown to decrease herd level SCC in national mastitis-control programs in Australia and The Netherlands (Brightling et al., 2009; Lam et al., 2011) and have resulted in reduced antimicrobial usage in organic dairy herds in Denmark (Bennedsgaard et al., 2010). However, randomized study designs were not used in these studies. In the Dutch study, herds participating in study groups had a lower herd-level SCC than herds from nonstudy group participants at the beginning of the study (Lam et al., 2011). The effectiveness of using study groups as an udder health-improvement strategy in dairy herds therefore remains uncertain.

Our study was designed as a multiarm randomized field trial to provide strong evidence for clinical decision making (Lavori and Kelsey, 2002). The aims of our study were to quantify the effectiveness of 3 udder health-improvement strategies by comparing them with a negative control group (NC). The 3 udder healthimprovement strategies evaluated were (1) personalized advice (as a positive control group; PC), (2) personalized advice plus veterinary support (VET), and (3) personalized advice plus participation in study groups (SG). It was hypothesized that written, herd-specific udder health improvement advice combined with a support strategy (either veterinary support or participation in a study group) would improve the mastitis management in dairy herds, resulting in improved udder health compared with negative control herds that did not receive udder health advice or support.

\section{MATERIALS AND METHODS}

Five trained veterinarians [L. Kretzschmar, B. Berchtold, F. Wohlfender, M. Harisberger, and A. Tschopp] visited each of the 100 participating herds during milking time from September to December 2011 and wrote herd-specific advice reports for the 75 herds assigned to 1 of the 3 study arms with an intervention (PC, VET, and SG). The reports included recommendations for improving udder health management. From January to December 2012, herds received the additional support according to their study arm assignment. After $1 \mathrm{yr}, 3$ veterinarians (L. Kretzschmar, D. Heiniger, A. Tschopp) visited all participating herds to reassess udder health management practices and to evaluate the implementation of the recommended management changes in the herds belonging to the 3 study arms with intervention.

\section{Sample Size}

Sample size calculation was based on the study of Green et al. (2007). In that study, the SD of the proportional change in mastitis outcome was 0.25 across all study participants. Together with a power of $80 \%$, a type 1 error of $5 \%$, an effect size of $20 \%$ reduction in within-herd prevalence of cows with an elevated composite SCC, and 4 study arms, 19 subjects were needed per study arm according to Power Analysis and Sample Size 12.0 (PASS; NCSS LLC, Kaysville, Utah) software. The final sample size was set to 25 participants in each study arm to compensate for loss to follow up and for multiple comparisons between the 4 study arms. 


\section{Inclusion and Exclusion Criteria and Enrollment of Herds}

The 3 Swiss dairy breeding organizations (Swiss Brown Cattle Breeders' Federation, Zug, Switzerland; Holstein Breeders' Federation, Posieux, Switzerland; and Swissherdbook, Zollikofen, Switzerland) were asked to identify all dairy herds that had an average yield-corrected bulk milk SCC (YCBMSCC; Lievaart et al., 2007) in 2010 between 200,000 and 300,000 cells/ $\mathrm{mL}$ and a herd size of $\geq 12$ lactating dairy cows at each test day. Herds were required to have $\geq 11$ test day measurements recorded at the same location in 2010 to exclude herds that send all their cows to a communal pasture. Herds located in the canton of Ticino were excluded because of logistic and language reasons. This resulted in a sampling frame of 1,553 herds. One thousand herds, stratified by breeding organization [Swiss Brown Cattle Breeders' Federation $(\mathrm{n}=400)$, Holstein Breeders' Federation ( $\mathrm{n}=200$ ), and Swissherdbook ( $\mathrm{n}$ $=400)$ ], were randomly selected from this database. A letter was sent by the breeding organizations to the farmers with an invitation to participate in the study. Of the herds that responded positively $(\mathrm{n}=140), 30$ herds were excluded because of inadequate bookkeeping records $(\mathrm{n}=26)$, an automatic milking system in place $(\mathrm{n}=3)$, and seasonal communal pasturing $(\mathrm{n}=$ 1). Another 10 herds were randomly excluded to meet the appropriate sample size.

\section{Randomization and Blinding}

Assigning farmers to the 4 study arms was conducted in 2 steps. In the first step, 4 regions with many herds in relatively close proximity were selected (the cantons of Bern, Luzern, and Thurgau and the cantons of Fribourg and Vaud combined; Figure 1) to avoid farmers having to travel long distances to participate in peer study group meetings (Vaarst et al., 2007). Herds in these 4 regions $(\mathrm{n}=50)$ were randomly assigned to the SG study arm in a ratio of 1:1 using computergenerated random numbers. This resulted in 1 study group with 5 herds (cantons of Fribourg and Vaud), 1 with 6 herds (canton of Bern), and 2 with 7 herds (cantons of Luzern and Thurgau). The 25 herds not assigned to the SG study arm were pooled with the 50 herds from the other regions and then randomly assigned to the other 3 study arms in a ratio of 1:1:1 using computer-generated random numbers. This second randomization step was stratified by canton to ensure that the 3 other study arms were evenly distributed throughout Switzerland. Herds were enrolled by LK, who, along with the study coordinator (B. H. P. van den Borne), generated the allocation sequence and assigned herds to the 4 study arms.

Due to the nature of our study, farmers could not be blinded to the udder health improvement strategy they received. Farmers were informed to which study arm they were assigned to and were required to actively participate in 1 of the support strategies if they were assigned to one (VET or SG).

\section{Herd Visits and Advice Report}

A standardized questionnaire was sent to all farmers before each of the 2 herd visits to collect general herd information (e.g., herd size, herd type, and number of cubicles), as well as information about herd health management, including udder health management. A visit protocol was developed to collect information about the housing system, the milking system, and the milking hygiene during the herd visits. The questionnaire and the visit protocol were based on current scientific and practical knowledge on udder health improvement in dairy herds and were pretested in 4 herds. The content was discussed among the veterinarians visiting the herds to reduce interobserver variability. The aims of the questionnaire and the visit protocol were to collect information about all relevant udder healthmanagement practices at the beginning and at the end of the intervention. A pragmatic approach was used to identify problem areas during herd visits because of time restrictions. Known cow-level mastitis risk factors (e.g., teat condition scores) were therefore assessed on a convenience sample of dairy cows in the herd. Together with the overall (subjective) assessment of the herd, based on the veterinarian's experience, the individual scores were used to assign the herd a semiquantitative risk factor score. Additionally, milk samples were taken during the farm visits to determine the mastitiscausative pathogens in the herd. Following the farm visit, every farmer enrolled in 1 of the udder healthimprovement strategies (PC, VET, and SG) received a herd-specific report with recommendations to improve the herd udder health management (Tables 1-5). Recommendations were summarized at the last page of the report and were categorized as the 3 most important recommendations, other short-term recommendations, and other long-term recommendations. The formats of the questionnaire, visit, and report were uniform for all herds and the native language of each farmer (i.e., German or French) was used. Each report was written by the veterinarian visiting the herd and was evaluated by 2 other project members with experience in udder health improvement in dairy herds (T. Kaufmann, M. Reist, or B. H. P. van den Borne). The reports were sent to the farmers within $40.6 \mathrm{~d}$, on average (SD: 12.9, 


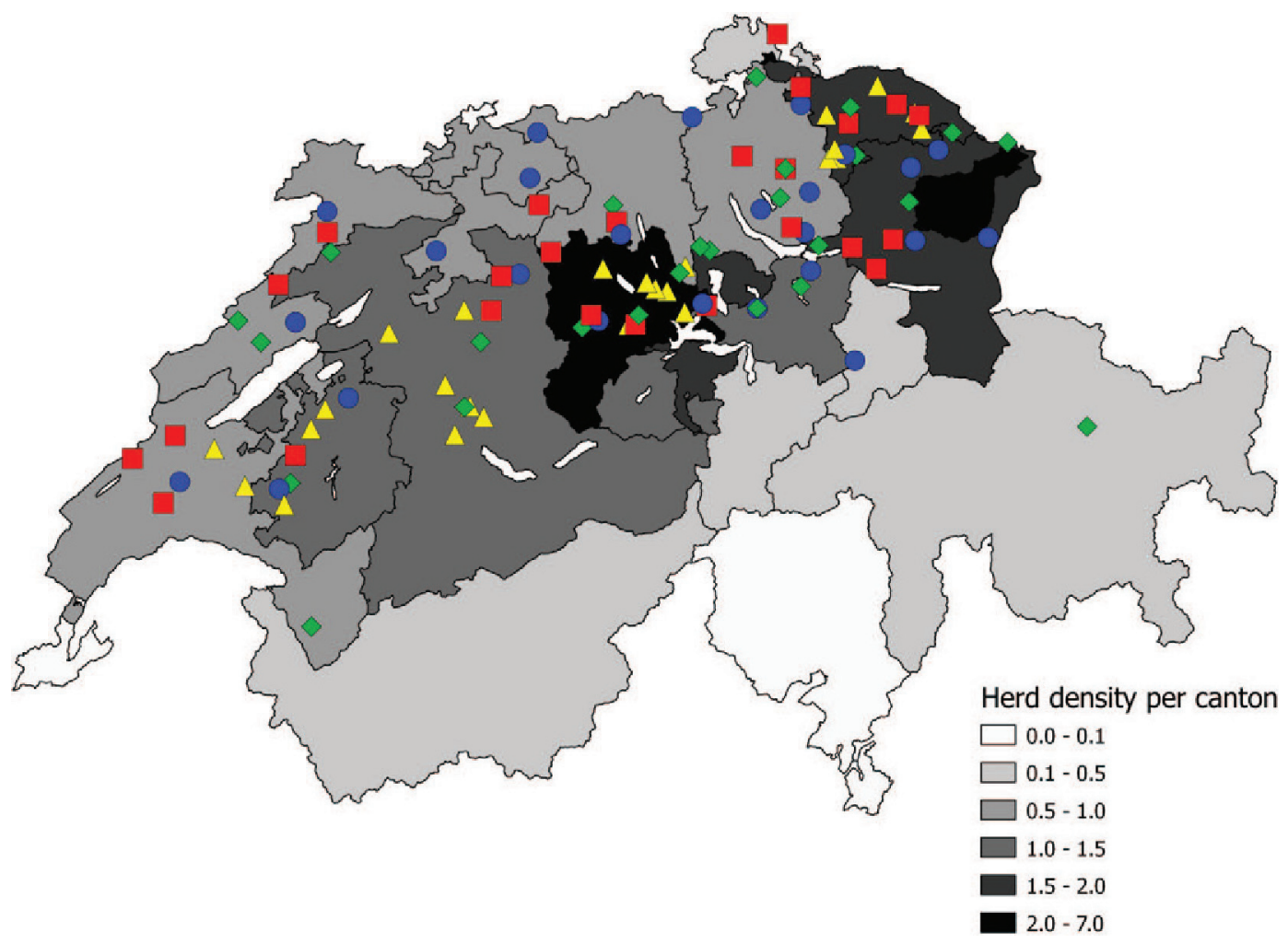

Figure 1. Geographical distribution of herds participating in the study. The location of participants in the negative control study arm ( $\square$; red), positive control study arm $(\diamond$; green), veterinary support study arm $(\bigcirc$; blue), and the study group study arm $(\Delta$; yellow) are plotted against the density of herds (number of herds per square kilometer) in Switzerland. Color version available online.

range: $19-77 \mathrm{~d}$ ), after the herd visit in autumn 2011. The date of sending the report was defined as the start of the intervention in each herd (mo 0). The last reports were sent in the first week of January 2012. As the NC study arm did not receive any advice reports in 2011, the median number of days between the first herd visit and the day of sending the report in the other 3 study arms (i.e., $40 \mathrm{~d}$ ) was added to the date of the first herd visit for the NC study arm. This new date was set as mo 0 for the herds in the NC study arm.

\section{Study Arms}

The first study arm (NC) served as a negative control group and did not receive any support during the study. These herds were visited and their udder health management was assessed, but they received neither an advice report nor any follow up during 2012. At the end of the study, after the second visit in autumn 2012, the farmers in this study arm received the same advice report that the other 3 study arms received in 2011.

The second study arm (PC) served as a positive control group and only received the advice report in autumn 2011. Herds in this study arm received no ad- ditional planned support during the study. However, farmers in this study arm were allowed to contact project members or their veterinarian for advice at their own initiative.

Farmers in the third study arm (VET) received an advice report at the start of the intervention and monthly visits by their herd veterinarian during the follow-up period. After each test day record, project members sent the herd veterinarian a task list. The goals of the task list were to identify and treat new IMI caused by major pathogens. Veterinarians were requested to (1) perform a California Mastitis Test (Sanford et al., 2006) on all cows with a new composite SCC $\geq 150,000$ cells $/ \mathrm{mL},(2)$ collect milk samples from quarters having a positive result ( ++ or higher), and (3) submit milk samples to a diagnostic laboratory of their choice for bacteriological examination. An antimicrobial treatment of cows subclinically infected with Staphylococcus aureus was requested and veterinarians had to take milk samples in subsequent herd visits to evaluate bacteriological cure after treatment. Milk composition (fat, protein, and urea) evaluation was performed by a project member (T. Kaufmann) and used to provide recommendations on how to improve 
Table 1. Frequency and implementation of recommendations regarding milking hygiene given to the 3 study arms that received an udder health improvement strategy

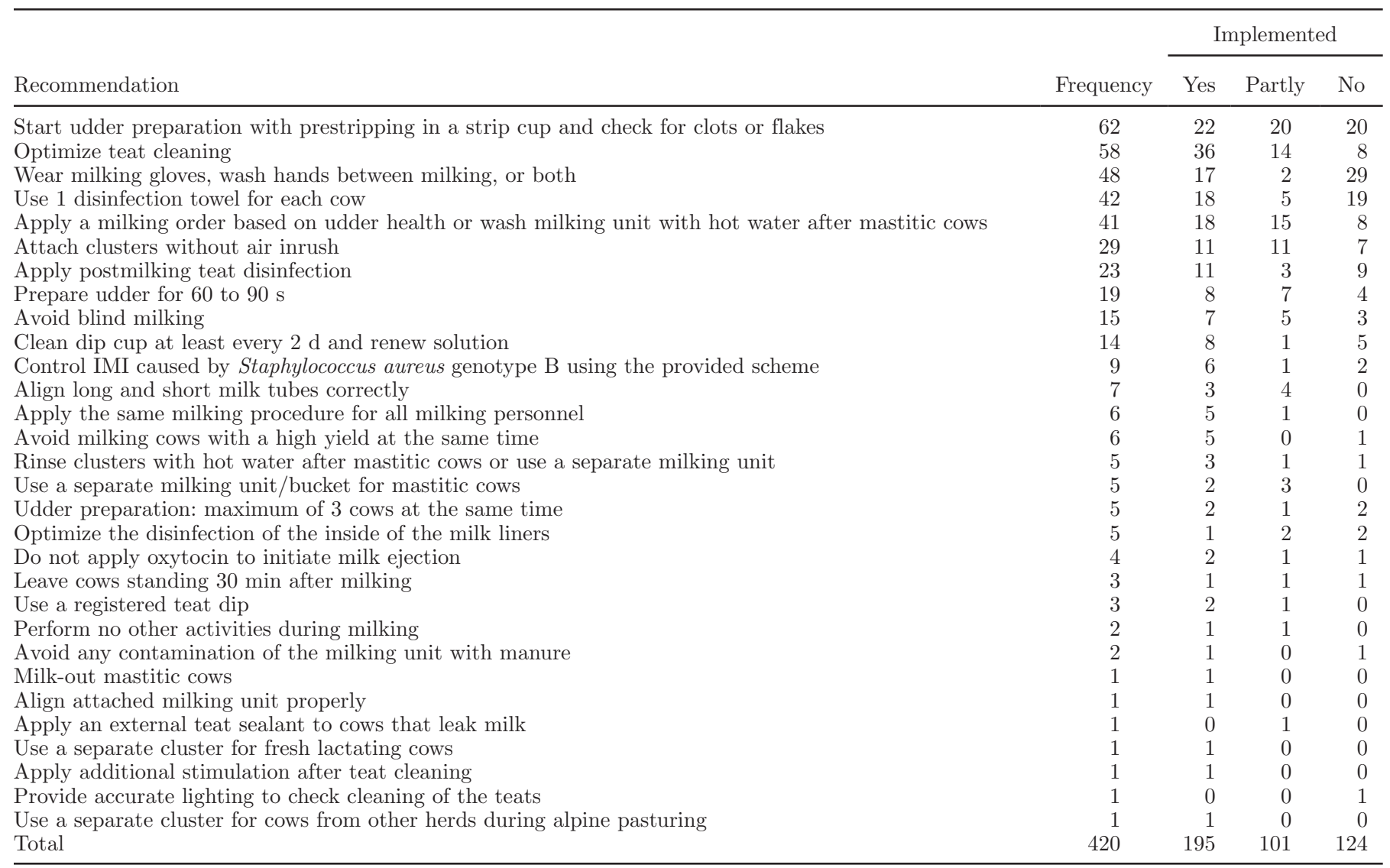

the ration. Veterinarians were requested to contact the farmer, discuss the task list, and send the completed list back together with the bacteriological results.

Each farmer enrolled in the fourth study arm (SG) received an advice report at the start of the interven- tion and were required to attend peer study group meetings during the follow-up period. Approximately once every 2 mo, project members, in collaboration with an experienced study group moderator (Vaarst et al., 2007), organized study group meetings dealing

Table 2. Frequency and implementation of recommendations regarding milking machine given to the 3 study arms that received an udder health improvement strategy

Recommendation

Let a technician check and correct the milking machine

Change teat liners within the recommended interval

Apply flexible connections between tank and piping

Install the vacuum pump on rubber buffers

Check service protocol

Clean the vacuum regulator

Use a new filter for every milking

Avoid vibrations from the vacuum pump being transmitted to the rest of the milking machine

Install vacuum regulator correctly

Cleaning with alkaline detergent every day and with acid detergent at least once per week

Apply a static milking test to your milking machine every year

Renew any separate milking unit and integrate them into the automatic washing process

Integrate all clusters in the automatic washing process and in the yearly milking machine test

Document the milking machine service

Total

Journal of Dairy Science Vol. 98 No. 2, 2015 mplemented

\begin{tabular}{crrr} 
& \multicolumn{3}{c}{ Implemented } \\
\cline { 2 - 4 } Frequency & Yes & Partly & No \\
\hline 71 & 34 & 20 & 17 \\
54 & 16 & 1 & 37 \\
34 & 7 & 6 & 21 \\
25 & 10 & 1 & 14 \\
10 & 8 & 0 & 2 \\
9 & 7 & 1 & 1 \\
7 & 2 & 1 & 4 \\
5 & 2 & 0 & 3 \\
2 & 1 & 0 & 1 \\
2 & 2 & 0 & 0 \\
1 & 0 & 1 & 0 \\
1 & 0 & 0 & 1 \\
1 & 1 & 0 & 0 \\
1 & 1 & 0 & 0 \\
223 & 91 & 31 & 101 \\
\hline
\end{tabular}


Table 3. Frequency and implementation of recommendations regarding environment and housing given to the 3 study arms that received an udder health improvement strategy

\begin{tabular}{lrrrr}
\hline & & \multicolumn{2}{c}{ Implemented } \\
\cline { 2 - 5 } Recommendation & Frequency & Yes & Partly & No \\
\hline Optimize hygiene of cubicles, remove manure more often & 31 & 17 & 9 & 5 \\
Optimize hygiene of cubicles, apply more straw & 29 & 11 & 9 & 9 \\
Run manure scraper more often & 19 & 11 & 4 & 4 \\
Optimize hygiene of cubicles, check cubicle sizes & 16 & 2 & 6 & 8 \\
Optimize hygiene of cubicles, apply lime regularly & 7 & 6 & 1 & 0 \\
Optimize hygiene of cubicles, set up a proper straw bedding & 3 & 0 & 0 & 3 \\
Optimize hygiene of cubicles & 2 & 2 & 0 & 0 \\
Use more straw in the deep straw housing & 2 & 2 & 0 & 0 \\
Check climate in the stable & 1 & 0 & 0 & 1 \\
Optimize ventilation, install windbreaker & 1 & 0 & 1 & 0 \\
Optimize straw bedding & 1 & 0 & 0 & 1 \\
Improve hygiene of cows, shave tails & 1 & 1 & 0 & 0 \\
Replace rubber mats & 1 & 1 & 0 & 0 \\
Apply efficient fly control & 1 & 0 & 0 & 1 \\
Do not wet the lying surfaces & 1 & 1 & 0 & 0 \\
Total & 116 & 54 & 30 & 32 \\
\hline
\end{tabular}

with various udder health topics. The farmers' herd veterinarians were also invited to attend. During the inaugural meeting, farmers were asked to discuss the advice report they received. Farmers were requested to publicly state which recommendations they wanted to implement during the coming year as this was assumed to improve their commitment (Lokhorst et al., 2013). Each farmer's commitments were recorded and minutes of the meeting were sent to all participants in the study group. During subsequent meetings, farmers continuously discussed the advice that was given and they were educated about different aspects of mastitis, such as milking technique, milking hygiene, diagnostics, feeding, therapy, and other topics, by project members and other experts in the field of udder health. Five to 7 peer study group meetings were organized depending on the size of the study group and the availability of the participants. Study group meetings always took place on the farm of 1 of the participants and were rotated to give farmers the opportunity to visit other dairy herds and to observe udder health-management practices of their peers.

Farmers were compensated for financial losses they had (e.g., bacteriological analyses, therapy, veterinary costs) for participating in the study. The compensation was 10, 20, 70, and 35 Swiss Francs per average cow being present in the herd in 2012 in the NC, PC, VET, and SG study arm, respectively.

\section{Mastitis Assessment}

Collection of Milk Samples. The following milk samples were collected in each herd: (1) individual quarter milk samples for bacteriological culture from each cow with a composite SCC $\geq 150,000$ cells $/ \mathrm{mL}$, taken under aseptic conditions before cluster attachment; (2) quarter milk samples from cows that were not milked into the bulk tank (i.e., cows treated with

Table 4. Frequency and implementation of recommendations regarding dry period given to the 3 study arms that received an udder health improvement strategy

\begin{tabular}{|c|c|c|c|c|}
\hline Recommendation & Frequency & \multicolumn{3}{|c|}{ Implemented } \\
\hline Dry off abruptly & 13 & 7 & 3 & 3 \\
\hline Use internal teat sealants for cows that leak milk & 6 & 1 & 1 & 4 \\
\hline Improve the feeding management during the dry period & 4 & 2 & 1 & 1 \\
\hline Apply selective dry cow treatment & 4 & 0 & 1 & 3 \\
\hline Check antimicrobial susceptibility of diagnosed pathogens before dry off & 1 & 0 & 1 & 0 \\
\hline Apply internal teat sealant to cows with a long expected dry period & 1 & 0 & 0 & 1 \\
\hline Total & 44 & 14 & 11 & 19 \\
\hline
\end{tabular}


Table 5. Frequency and implementation of recommendations regarding other issues given to the 3 study arms that received an udder health improvement strategy

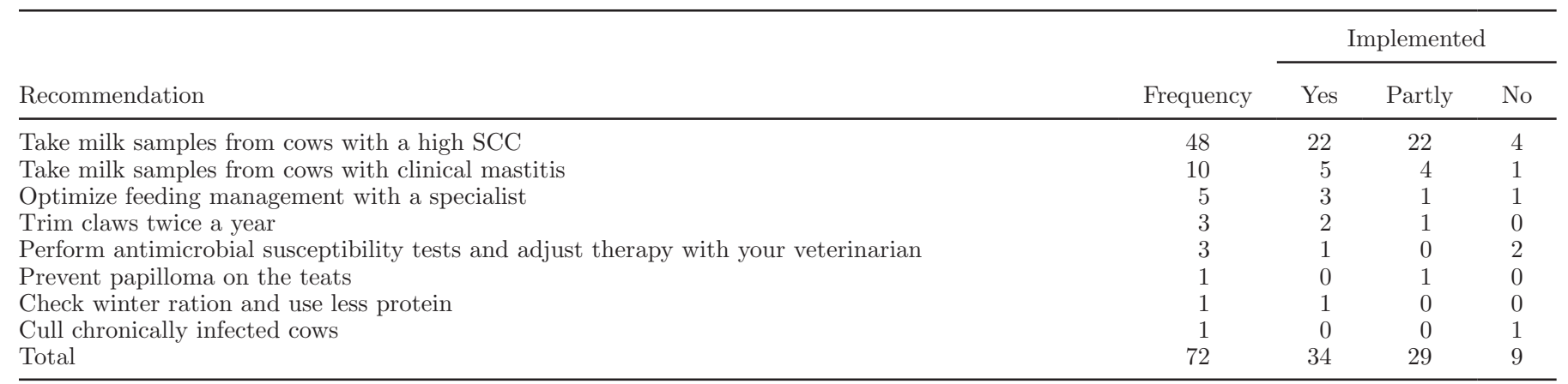

antibiotics and up to $8 \mathrm{~d}$ postpartum), taken for PCR testing directly after the first aseptic milk samples were taken (Syring et al., 2012); and (3) a bulk tank milk (BTM) sample taken after the milking process, following the guidelines of the National Mastitis Council (NMC, 1999). All samples were cooled during transport and were immediately stored at $-20^{\circ} \mathrm{C}$ until laboratory testing.

Laboratory results were used to classify herds as having udder health problems predominantly caused by either (1) contagious mastitis pathogens [i.e., Staph. aureus genotype B (GTB), other contagious Staph. aureus strains, nonenvironmental streptococci, or Corynebacterium spp.], (2) environmental mastitis pathogens (i.e., Escherichia coli, Streptococcus uberis, Streptococcus dysgalactiae, or noncontagious strains of Staph. aureus), or (3) both, if the proportions of contagious and environmental pathogens were approximately equal (Green et al., 2007). The latter category included herds with a high within-herd CNS prevalence. Herd composite SCC patterns [i.e., annual prevalence of high $(\geq 150,000$ cells $/ \mathrm{mL})$ composite SCC measurements, annual proportion of test day measurements with a new high composite SCC, and annual proportion of cows having a high composite SCC at the start of the lactation; de Haas et al., 2004] were additionally used to classify herds if laboratory results were not conclusive. Analogous to Green et al. (2007), they were used also to identify whether new infections were mainly occurring during lactation, during the dry period, or both. Herd classifications were used to develop and prioritize herd-specific recommendations for optimizing the herd udder health management.

Bacteriological Culture. Aseptically taken quarter milk samples were sent to the Institute for Food Safety and Hygiene in Zürich, Switzerland, where bacteriological culturing was performed according to National Mastitis Council guidelines (NMC, 1999). Additionally, the penicillin sensitivity of Staph. aureus and CNS isolates was determined using the agar diffusion test.
Detection of Staph. aureus GTB. After defrosting, a new pooled BTM sample was created by pooling equal volumes of quarter milk of cows not milked into the bulk tank to milk from the original BTM sample. The amount of original BTM added was relative to the number of dairy cows milked into the bulk tank. These pooled BTM samples were tested for the presence of Staph. aureus GTB using an established PCR assay (Boss et al., 2011; Syring et al., 2012) performed by Agroscope (Bern, Switzerland). These analyses, in combination with the results of the bacteriological culturing, allowed the classification of Staph. aureus-positive herds in herds being Staph. aureus GTB-positive and herds being positive for other Staph. aureus genotypes. Differentiating Staph. aureus GTB from other genotypes was considered important because this genotype has been suggested to be contagious in Swiss dairy herds, based on a high within-herd prevalence (Graber et al., 2009) and the ability to strongly increase it in a short period of time (Voelk et al., 2014). Herds enrolled in the PC, VET, and SG study arms that were positive for Staph. aureus GTB were offered an additional control program for this genotype. In this control program, composite milk samples from lactating cows collected during each monthly test day were tested to identify new Staph. aureus GTB IMI. They were collected at the responsible laboratory (Suisselab, Zollikofen, Switzerland) and were subsequently shipped to the laboratory of Agroscope for PCR testing according to Syring et al. (2012). Tests results were used to strictly determine the milking order in participating herds each month; Staph. aureus GTB-positive cows were milked last or with a separate cluster.

\section{Collection of Mastitis Data}

Monthly composite SCC data from all cows present in participating herds were obtained from the 3 Swiss breeding organizations. The implementation of each recommendation in the 3 study arms with an udder 
health-improvement strategy was evaluated during the second herd visit by observations made during milking time or, alternatively, through discussions with the farmer. Recommendations were rated as being completely, partially, or not implemented. For instance, if the recommendation was to apply postmilking teat disinfection, the frequency of postmilking disinfection (applied to every cow, applied to some cows, or not applied to any cows) would have determined if this recommendation was completely, partially, or not implemented.

According to Swiss law, all antimicrobial treatments must be recorded in the herd's treatment journal. The date, identification number of the treated animal, reason for treatment, duration of treatment, brand name of the product, and the withdrawal time are required to be recorded. Treatment journals from the years 2010 through 2012 were obtained from all participating herds.

\section{Definition of Outcomes}

Primary Outcome: Prevalence. The within-herd prevalence of cows with an elevated composite SCC (PREV) was the primary outcome of this study. It was calculated as the monthly herd-level proportion of lactating cows with a composite $\mathrm{SCC} \geq 200,000$ cells/ $\mathrm{mL}$ (van den Borne et al., 2010).

Secondary Outcomes: Degree of Implementation and Management Error Scores. Secondary outcomes were used to determine whether recommendations to improve udder health management were associated with a corresponding change. The degree of implementation metric was whether recommendations were completely, partially, or not implemented and was assessed in the 3 study arms with an udder health improvement strategy only.

Management error scores were used to evaluate udder health-management practices in all 4 study arms. They were a measure of the management errors in the broad topics of milking machine (maximum number of errors $=6$ ), milking hygiene (maximum number of errors $=21$ ), and other (maximum number of errors $=17$ ). The total number of management errors observed was summed into a fourth overall management error score (maximum number of errors $=44$; Table 6 ). Management error scores were quantifying the number of mastitis prevention practices that were not being implemented in a herd. Information collected on questionnaires and herd visits were used to identify management errors. Data from mastitis prevention practices having an ordinal or continuous scale were assigned a binomial distribution first to be able to include them in the management error scores. This was done using existing good practice guidelines from service providers or scientific literature as defined in Table 6. Mastitis prevention practices were equally weighted in each management error score. The 44 management errors were selected because they were measureable in all herds and considered important for improving udder health in Swiss dairy herds.

Tertiary Outcomes: Annual Herd-Level Proportion of New SCC Infections and the Incidence Rate of Treated Mastitis Cases. A cow with an increase in composite SCC from below to above 200,000 cells $/ \mathrm{mL}$ on 2 consecutive test day recordings was defined as having a new infection (NI; Green et al., 2007), regardless whether a dry period or possible on- and off-farm movements (e.g., because of market, exposition, or communal pasturing) were in between the 2 test day recordings. Freshly calved heifers with a composite SCC $\geq 200,000$ cells $/ \mathrm{mL}$ on their first test day were also defined as having an NI (Green et al., 2007). The annual herd-level proportion of NI was evaluated as a tertiary outcome for both the years before and after the report was sent (mo 0). It was calculated as the sum of all NI divided by the sum of all test day recordings $<200,000$ cells $/ \mathrm{mL}$ in the previous test day for each study year (Green et al., 2007).

The number of treated mastitis (TM) cases was also evaluated as a tertiary outcome. Each farmer-reported mastitis treatment was considered to be a case, as an explicit distinction between clinical and subclinical mastitis cases could not be made based on the information provided. Treated mastitis cases involving the same quarter within an interval of $14 \mathrm{~d}$ were considered to be the same event and only counted once (Barkema et al., 1998). Treatments with long-acting antimicrobials at drying off were not classified as TM cases. The incidence rate of TM cases (IRTM) in each herd in the year before and after sending the report was calculated as the sum of all treated quarter mastitis cases divided by the number of cow-years at risk, which included all primi- and multiparous cows present in the herd (Green et al., 2007).

\section{Statistical Analysis}

Data obtained from all herd visits and questionnaires were entered into spreadsheets (Microsoft Access and Excel, Redmond, WA). Chi-squared and Fisher exact tests were used to determine whether the distribution of the herds' demographic characteristics differed between the 4 study arms. All other statistical analyses were performed with PROC GENMOD and PROC GLIMMIX in SAS 9.3 (SAS Institute Inc., Cary, NC). Multivariable population-averaged regression models were used to determine the effect of the 3 udder health- 
Table 6. Errors in management contributing to the 3 management error scores

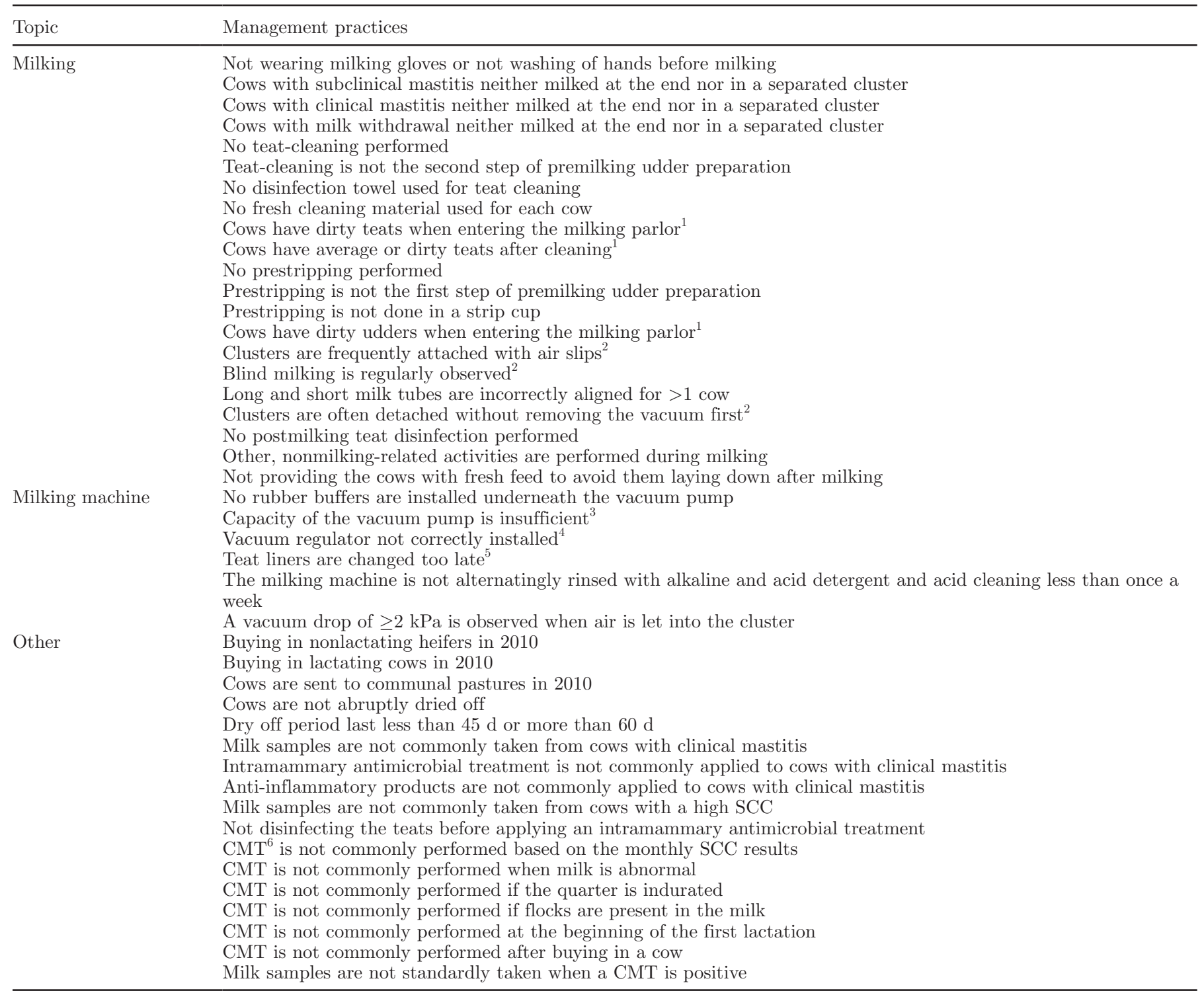

\footnotetext{
${ }^{1}$ Based on an overall score (clean, average, dirty) of the entire herd.
}

${ }^{2}$ Based on an overall observation of the entire herd.

${ }^{3}$ Current capacity pump - $(250+80 \times$ number of clusters $)<0$ (in L/min; Eidgenössisches Volkswirtschaftsdepartement, 2006).

${ }^{4}$ Regulator not placed between vacuum pump and first cluster, not macroscopically free from dust or dirt, or not mounted in the correct angle. ${ }^{5}$ Rubber teat liners are changed after more than $750 \mathrm{~h}$ of use (including washing); silicon teat liners are changed after more than $1,500 \mathrm{~h}$ of use. ${ }^{6}$ California Mastitis Test.

improvement strategies on the change in mastitis management and the 3 different mastitis indicators (PREV, NI, and IRTM). Significance was set at $P<0.05$. All models were checked for confounding which was assumed to occur when model estimates changed more than $25 \%$ when adding or removing a covariate.

Degree of Implementation. Recommendations for improvement of udder health management were categorized according to their topic: milking hygiene, milk- ing machine, environment or housing, dry period, or other (Tables 1-5). Multivariable population-averaged multinomial logistic regression models, correcting for clustering of recommendations within dairy herds, were built to evaluate the effect of covariates on the degree of implementation (not, partially, completely) of each recommendation in the 3 study arms with an udder health-improvement strategy. All covariates considered to be biologically relevant were tested and included: 
study arm (PC, VET, or SG), topic, priority (most important, other short-term, other long-term), study veterinarian performing the first herd visit (5 categories), study veterinarian performing the second herd visit (3 categories), the language of the farmer (German, French), and Staph. aureus GTB status (Staph. aureus GTB-negative, Staph. aureus GTB-positive but not participating in the additional control program, Staph. aureus GTB-positive and participating in the additional control program). Farmers were asked which study arm they preferred to be assigned to during the enrollment phase of the study. This did not affect the outcome of the study arm assignment (it was conducted randomly), but the result of this process (no preference or assigned to the preferred study arm versus not in the preferred study arm) was evaluated as an additional binomial covariate. All variables with a univariable association with the degree of implementation $(P<0.25)$ were selected for the multivariable models in which a backward selection process was performed until all variables were significantly $(P<0.05)$ associated with the degree of implementation. Two-way interactions were also evaluated.

Management Error Scores. Changes in management error scores between the 2 herd visits for the 4 study arms were evaluated using population-averaged Poisson regression models for each of the 4 management score categories separately. The number of management practices being absent at each herd visit was used as the dependent variable, whereas the natural logarithm of the number of evaluated management practices was used as the offset. Autoregressive correlation structures were added to the models to correct for repeated visits to each herd. Herd visit (first or second), study arm (4 categories), and their interaction were evaluated as fixed effects in each model. The Type 3 Wald test was used to select the best-fitting model.

Mastitis Indicators. Herds needed to have a YCBMSCC between 200,000 and 300,000 cells/mL in 2010 to be selected for the study. However, many herds improved their YCBMSCC status until the beginning of the intervention (September-December 2011). The average YCBMSCC of the 6 mo before sending the report was therefore calculated and herds were subsequently classified as either having a low $(<200,000$ cells $/ \mathrm{mL})$ or high $(\geq 200,000$ cells/mL) YCBMSCC status at mo 0 .

The effect of different udder health-improvement strategies on the 3 mastitis indicators (PREV, NI, and IRTM) was assessed with population-averaged regression models correcting for repeated measures within herds. Negative binomial distributions were used for the PREV and IRTM mastitis outcomes. The number of cows with a composite $\mathrm{SCC} \geq 200,000$ cells $/ \mathrm{mL}$ at each test day and the number of annual TM cases, respectively, were used as the outcome variables in these models. The natural logarithm of the number of lactating cows at each test day and the natural logarithm of the number of cow days at risk, respectively, were used as offsets. A linear distribution was fit for the NI mastitis outcome. Study arm (4 categories), YCBMSCC status at mo 0 (2 categories), a time component, and their 2- and 3-way interactions were evaluated in all statistical models investigating the 3 mastitis outcomes. Based on the within-herd prevalence of Staph. aureus IMI, as determined by the bacteriological culture results, recommendations for improvement might have been prioritized differently between Staph. aureus GTB-positive herds and herds positive for other Staph. aureus genotypes. Staphylococcus aureus GTB-positive herds were also offered an additional control program. The Staph. aureus GTB status of each herd (Staph. aureus GTB-negative, Staph. aureus GTB-positive but not participating in the additional control program, Staph. aureus GTB-positive and participating in the additional control program) was therefore added as an additional covariate to each statistical model. Its 2-way interaction with the time component was additionally evaluated if the main effect was significant. The time component differed between the 3 mastitis indicators. For PREV, the study period was divided in 3 phases: -6 to $\geq 0,1$ to $\geq 4$, and 5 to $\geq 12$ mo; whereas, for NI and IRTM, the year before and after mo 0 were compared. A combination of sine-cosine components was additionally added to the model for PREV to correct for seasonal changes in this mastitis outcome (van den Borne et al., 2010). Backward analyses, using the Type 3 Wald test, were used to select the best fitting model. The 3 study arms with intervention were merged into a new study arm (intervention; INT) if initial data exploration identified no significant differences between them. The same models were subsequently built using this new binomial variable (INT vs. NC) to evaluate the effect of any udder health-improvement strategy on the 3 mastitis outcomes.

The Hawthorne effect is defined as a problem in field trials where participants modify their behavior because of awareness of being a subject in a study, thereby affecting the study outcome (Adair, 1984; Main et al., 2012). The development of the primary outcome of this study (PREV) in the NC study arm was checked for a possible Hawthorne effect by comparing it with a new group of dairy herds. This additional group consisted of herds that positively replied to participate in the study but were not enrolled. Neither the nonparticipating herds nor the NC study arms herds received an advice report and, hence, the start of the intervention 
(mo 0) could not be defined. Thus, the analyses were performed using 3 newly defined study periods: July to December 2011, January to June 2012, and July to December 2012. Except for the time component, the same statistical model as described previously for PREV was applied to evaluate a potential Hawthorne effect in the current study.

\section{RESULTS}

One farmer in the VET study arm was lost to followup, leaving 99 herds available for statistical analyses. The median herd size was 28 (range: 13-116) dairy cows. The median percentage of cows with a composite SCC $>200,000$ cells $/ \mathrm{mL}$ at the last test day record before the first herd visit was $23.3 \%$ (range: $0.0-57.9 \%$ ) and the median YCBMSCC was 179,000 cells $/ \mathrm{mL}$ (range: 55,000-502,000 cells/mL). Bacteriological results of milk samples on the quarter, cow, and herd level are shown in Table 7. The highest quarter- and cow-level prevalence was observed for Corynebacterium bovis (14.0 and $28.6 \%$ respectively), and it represents the second-highest prevalence at the herd level (74.8\%). The CNS showed the highest herd-level prevalence, with $82.8 \%$. More than half $(51.5 \%)$ of the herds had $\geq 1$ cow positive for Staph. aureus.

The geographical distribution of participating herds is shown in Figure 1. Demographic characteristics of participating herds are presented in Table 8. Forty-one herds had a low YCBMSCC at mo 0; the other 58 herds still had a high YCBMSCC. The majority of herds (80 out of 99) were located in the German-speaking part of Switzerland. Furthermore, 14 herds were positive for Staph. aureus GTB, of which 5 participated in the additionally offered control program for this Staph. aureus genotype. No significant differences were observed in the distribution of the characteristics in the study arms, except farmer preference for a study arm $(P=$ $0.02)$. This was most likely caused by the fact that $44 \%$ of the farmers preferred to be in the VET study arm at the start of the study.

\section{Recommended Changes in Mastitis Management}

After the first herd visits, a total of 875 recommendations were given to the 3 study arms with intervention, belonging to 77 different recommendations (Tables 1-5). Most recommendations were given in the topic milking hygiene $(\mathrm{n}=420)$, followed by the topics milking machine $(\mathrm{n}=223)$, environment or housing $(\mathrm{n}=116)$, other $(\mathrm{n}=72)$, and dry period $(\mathrm{n}=44)$. Overall, $44.3 \%$ of the recommendations were completely implemented, whereas $23.1 \%$ were partly and $32.6 \%$ were not implemented. The results of the final population-averaged multinomial logistic regression model identifying covariates associated with the degree of implementation of recommendations are shown in Table 9. Farmers who were assigned to their preferred study arm at the start of the intervention implemented significantly more recommendations than the farmers who were not assigned to their preferred study arm. Also, farmers implemented significantly more recommendations in the topics milking hygiene, environment or housing, and other compared with the topic milking machine. No significant differences in the degree of implementation of recommended management changes were observed between the 3 study arms with an udder health-improvement strategy.

\section{Management Error Scores}

In Table 10, the distributions of the management error scores are presented. The final multivariable Poisson regression models revealed significant main effects for herd visit for the milking machine $(P=0.0059)$ and milking hygiene $(P<0.0001)$ management errors scores. This implies that all 4 study arms had significantly less management errors for those 2 scores at the second herd visit compared with the first herd visit. A significant interaction term between herd visit and study arm was identified in the final statistical models for the other $(P=0.0014)$ and the total $(P=0.0031)$ management error scores. The VET, SG, and PC study arms had significantly less management errors at the

Table 7. Prevalence of mastitis pathogens in 4,227 quarters of 1,059 cows in 99 Swiss dairy herds

\begin{tabular}{lccc}
\hline & \multicolumn{3}{c}{ Prevalence $(\%$, with 95\% CI in parentheses) } \\
\cline { 2 - 4 } $\begin{array}{l}\text { Mastitis-causing } \\
\text { pathogens }\end{array}$ & Quarter level & Cow level & Herd level \\
\hline Streptococcus uberis & $4.9(4.3-5.6)$ & $14.4(12.4-16.6)$ & $64.7(54.8-73.4)$ \\
Streptococcus dysgalactiae & $1.0(0.8-1.4)$ & $3.5(2.6-4.8)$ & $20.2(13.5-29.2)$ \\
Staphylococcus aureus & $5.3(4.7-6.0)$ & $13.8(11.8-16.0)$ & $51.5(41.8-61.1)$ \\
CNS & $8.7(7.9-9.6)$ & $25.3(22.8-28.0)$ & $82.8(74.2-89.0)$ \\
Corynebacterium bovis & $14.0(12.9-15.0)$ & $28.6(26.0-31.4)$ & $74.8(65.4-82.3)$ \\
\hline
\end{tabular}


Table 8. Demographic characteristics of dairy herds in the negative control (NC), positive control (PC), veterinary support (VET), and study group support (SG) study arms

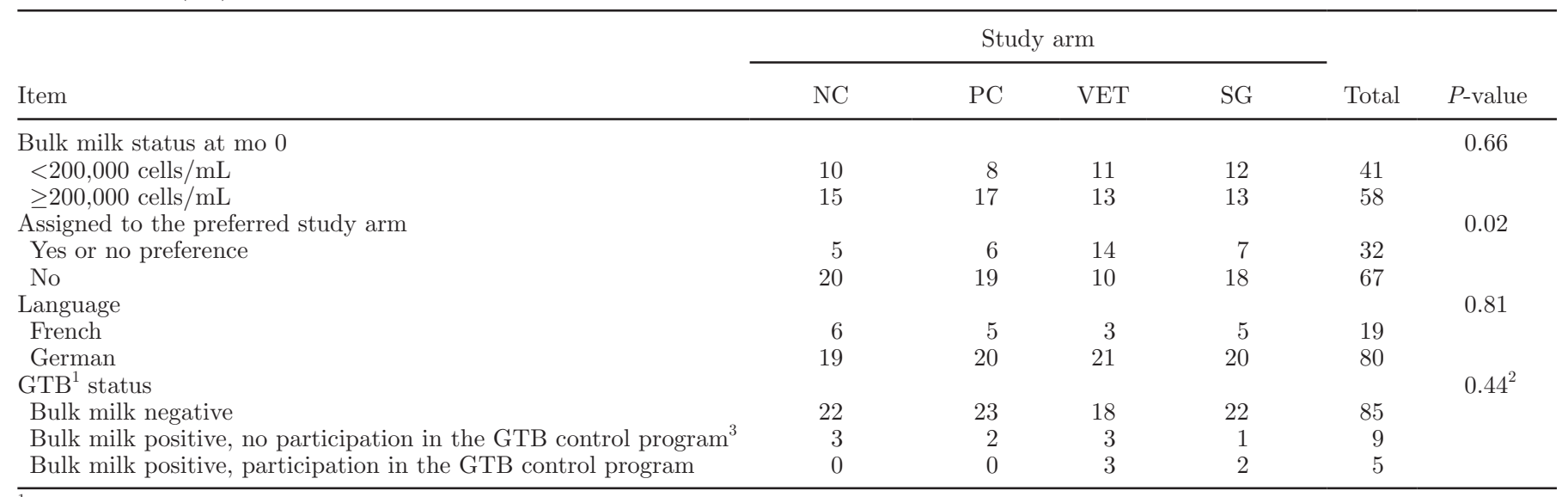

${ }^{1}$ Staphylococcus aureus genotype B.

${ }^{2}$ The difference in herds bulk milk Staph. aureus GTB-positive or bulk milk Staph. aureus GTB-negative was determined in this test.

${ }^{3}$ An additional control program for Staph. aureus genotype B was offered to herds in the PC, VET, and SG study arms being positive for this Staph. aureus genotype.

second herd visit compared with the first herd visit, whereas the number of management errors in the $\mathrm{NC}$ study arm did not change.

\section{Prevalence}

Initial data exploration identified no statistical differences in the change in PREV between the 3 study arms with an udder health improvement strategy. These 3 study arms (INT) were therefore jointly compared with the NC study arm. The results of the final population-averaged negative binomial regression model are presented in Table 11. After correcting for seasonal differences, the final model identified a 3-way interaction between study arm, phase, and YCBMSCC status at mo 0. The observed PREV for this 3-way interaction are shown in Figure 2 to facilitate interpretation. The within-herd prevalence of high-SCC cows was constant throughout the study in INT herds with a low YCBMSCC status at mo 0 . However, an increase after mo 0 could be observed in the NC herds with a low YCBMSCC status at mo 0 , which became significant $(P=$ 0.04; Table 11) in the last phase of the study period (4 to $\leq 12 \mathrm{mo}$ ). The incidence rate ratio in the last phase of the study period in herds with a low YCBMSCC status at mo 0 was 1.38 times (95\% CI: $1.11-1.72$ ) lower in the INT study arm than in the NC study arm. No effect of intervention could be observed in the herds with a high YCBMSCC status at mo 0. Herds participating in the additional Staph. aureus GTB-control program had a consistent higher PREV during the study period compared with Staph. aureus GTB-negative herds. The statistical models comparing the NC study arm with the herds not participating in the study $(\mathrm{n}=32)$ showed no significant difference between those 2 groups of herds, implying that a Hawthorne effect was not observed.

\section{Annual Herd-Level Proportion of New Infection}

The final linear regression model investigating NI is presented in Table 12. Herds with a high YCBMSCC status at mo 0 and herds participating in the additional Staph. aureus GTB-control program had both a consistently higher NI throughout the study than herds with a low YCBMSCC status at mo 0 and Staph. aureus GTB-negative herds, respectively. No significant differences between the 4 study arms over time were identified.

\section{Incidence Rate of Treated Mastitis}

In the PC study arm, 2 farmers did not provide their treatment journals. Evaluation of IRTM was therefore based on 25, 23, 24, and 25 herds in the NC, PC, VET, and SG study arms, respectively. The final populationaveraged negative binomial regression model is presented in Table 13. Herds with a high YCBMSCC status at mo 0 had a consistently higher IRTM compared with herds with a low YCBMSCC status at mo 0, regardless of the study arm they were in. An interaction term between study arm and study year was identified. The observed IRTM in the 4 study arms over time is therefore displayed in Figure 3 to facilitate interpretation. Post hoc analysis identified no significant differences in IRTM between the 4 study arms in the year before sending the report when changing the reference catego- 


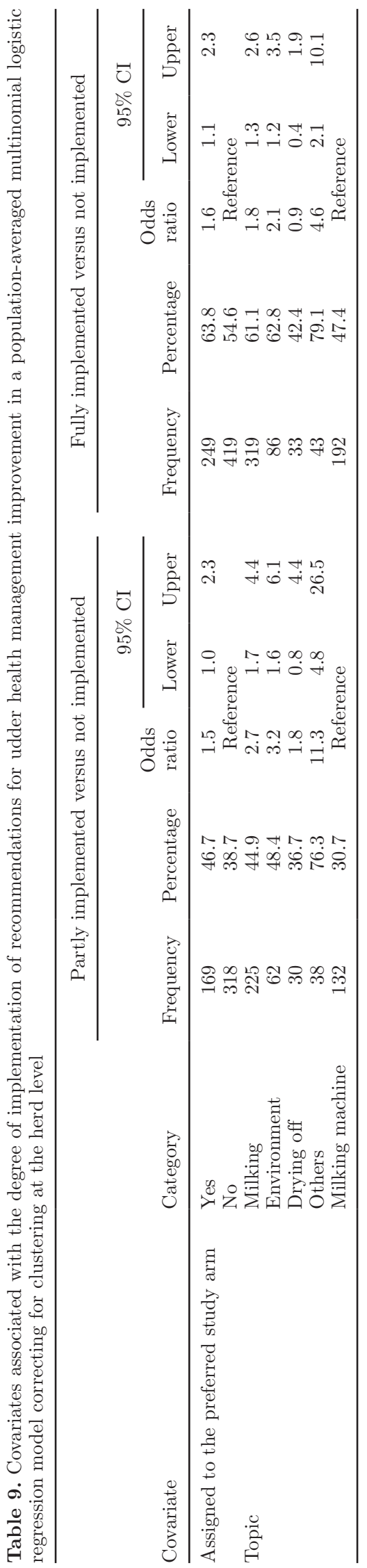

ries in the final statistical model $(P=0.18)$. Moreover, no significant differences in IRTM between the year before and after sending the report (mo 0) were identified in the $\mathrm{NC}(P=0.89$; Table 13$)$ and $\mathrm{PC}(P=$ 0.62 ) study arms. Instead, the VET study arm showed a borderline nonsignificant increase in IRTM in the year after sending the report $(P=0.05)$ compared with the year before sending the report. Also, a significant decrease in IRTM in the year after sending the report was observed in the SG study arm $(P=0.01)$ compared with the year before sending the report.

\section{DISCUSSION}

Our study aimed to quantify the effectiveness of 3 udder health-improvement strategies by comparing them with a control group not receiving any support. Based on a similar intervention study conducted in the United Kingdom (Green et al., 2007), the hypothesis tested was that written, herd-specific udder health advice with or without an additional support strategy would result in improved udder health in Swiss dairy herds. The UK intervention study reported a significant reduction in the proportion of cows with clinical mastitis (22\%), as well as a reduction in the incidence of clinical mastitis (20\%) and occurrence of NI (21\%) within 1 yr compared with control herds (Green et al., 2007). Similar improvements were not observed in the current study. Although advice tailored to each herd were provided in both studies, some differences were noted that influenced their comparability. First, the udder health status of the UK herds was poorer at the beginning of the study than the herds participating in the current study. Improvements in udder health are much easier to achieve when initial udder health is poor (Green et al., 2007; Jansen et al., 2010b; van den Borne et al., 2014). Second, one of the main selection criteria for herds participating in the UK study was the incidence rate of clinical mastitis. Selection for inclusion in the present study was based on herds having a YCBMSCC between 200,000 and 300,000 cells/mL. Mastitis pathogens were mainly of environmental origin in the UK study (Bradley et al., 2007), whereas they were more of contagious origin in the current study (Table 7; Kretzschmar et al., 2013). Different mastitis pathogens require different changes in management practices to achieve an improvement (Barkema et al., 1999; Huijps et al., 2010; Green et al., 2007).

Several reasons may explain why no reduction in PREV in herds with high YCBMSCC status at mo 0 was observed. Suboptimal mastitis management is the first potential reason. Both the degree of implementation of recommendations and the management error scores demonstrated that participants made most 
Table 10. Distribution of the management error scores in the topics milking hygiene, milking machine, other, and total for the 4 study arms in 2011 and 2012

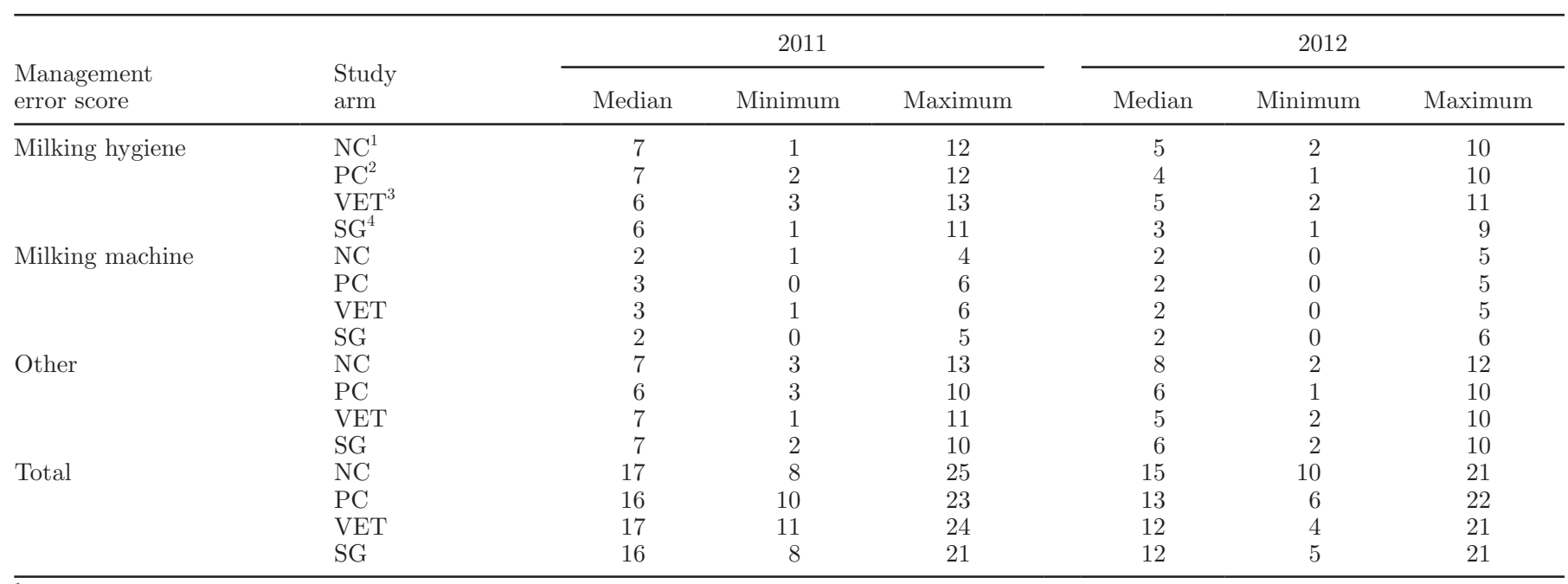

${ }^{1}$ Negative control study arm.

${ }^{2}$ Positive control study arm.

${ }^{3}$ Study arm with veterinary support.

${ }^{4}$ Study arm with study group meeting support.

of the changes in management practices in the topic other. Recommendations in the topic milking machine were the least frequently implemented. Furthermore, the study participants in all 4 study arms, including the NC study arm, made comparable changes in the categories milking hygiene and milking machine, as evident by a corresponding change in the management error scores in those 2 topics. The decrease in the total management error score in the 3 study arms with an intervention compared with the NC study arm was due almost entirely to a reduction in the other management error score (e.g., drying off, diagnosis, and treatment). Low compliance in the categories milking hygiene and milking machine might explain the lack of improvement in PREV. Milking order and milking machine management are key areas of management for controlling contagious IMI (Barkema et al., 2009), which many herds were experiencing problems with (Kretzschmar et al., 2013). Reasons for the lack of implementation of recommendations were not assessed in the current study, but it can be speculated that the low compliance in these 2 topics could be because their implementation requires a change in working routine (which is difficult to achieve) or large financial investments (Huijps et al., 2009). However, costs are not always reported as the major limitation for implementing recommendations (Sorge et al., 2010).

Implementation of recommendations for udder health-management improvement was generally moderate and may also explain that no reduction in PREV could be observed. A high degree of farmer compliance is expected to improve herd health management, which is assumed to result in improved herd health (Green et al., 2007; Sorge et al., 2010). The influence of farmer compliance was tested in the current study but was not associated with the primary outcome (PREV). No significant difference in PREV was noted between herds with high compliance scores and herds with low compliance scores in the final statistical model (data not shown). Reasons for the overall moderate implementation of recommendations are unclear because advice being given was standardized and herd-specific and room for improvement in mastitis management was observed in participating herds (Kretzschmar et al., 2013). Factors that may have influenced farmer compliance include too many recommendations being given to the farmers at one time (Sorge et al., 2010), failure to clearly emphasize the most important recommendations to farmers, communication of recommendations may not have been fully understandable to farmers, or famers may not have been able to translate the recommendations into a specific management behavior. Finally, farmers may have perceived that a change in management was not necessary because they may have felt that their udder management was sufficient, even if this was not the case (Sorge et al., 2010). Despite the moderate implementation of recommendations, it is interesting to note that farmers who were assigned to the study arm of their preference at the start of the intervention implemented 1.5 times more recommendations than the farmers who were not assigned to the study arm of their preference. Based on the results 
Table 11. Covariates associated with the within herd prevalence of cows with a composite somatic cell count $\geq 200,000$ cells/mL in a population-averaged negative binomial regression model correcting for clustering at the herd level

\begin{tabular}{|c|c|c|c|c|c|}
\hline Variable & Category & Estimate & $\mathrm{SE}$ & $P$-value & $\begin{array}{l}\text { Overall } \\
P \text {-value }\end{array}$ \\
\hline Intercept & & -1.35 & 0.10 & $<0.001$ & \\
\hline Sin & & -0.12 & 0.02 & $<0.001$ & $<0.001$ \\
\hline \multirow{2}{*}{ Study arm } & $\mathrm{INT}^{1}$ & -0.32 & 0.11 & 0.01 & 0.01 \\
\hline & $\mathrm{NC}^{2}$ & Reference & - & - & \\
\hline \multirow[t]{3}{*}{ Phase } & Phase $1^{3}$ & -0.24 & 0.10 & 0.01 & 0.04 \\
\hline & Phase $2^{4}$ & -0.03 & 0.10 & 0.72 & \\
\hline & Phase $3^{5}$ & Reference & - & - & \\
\hline \multirow[t]{2}{*}{ Bulk milk SCC status } & $\geq 200,000$ cells $/ \mathrm{mL}$ (high SCC) & -0.06 & 0.13 & 0.64 & 0.64 \\
\hline & $<200,000$ cells $/ \mathrm{mL}$ (low $\mathrm{SCC})$ & Reference & - & - & \\
\hline \multirow[t]{3}{*}{ GTB status $^{6}$} & Bulk milk positive, participation in GTB control program & 0.24 & 0.04 & $<0.001$ & $<0.001$ \\
\hline & Bulk milk positive, no participation in GTB control program & 0.12 & 0.09 & 0.15 & \\
\hline & Bulk milk negative & Reference & - & - & \\
\hline \multirow{7}{*}{ Interaction: Study arm $\mathrm{x}$ phase $\mathrm{x}$ bulk milk SCC status } & INT with high SCC in phase 1 & 0.64 & 0.22 & 0.003 & \multirow{7}{*}{0.01} \\
\hline & INT with high SCC in phase 2 & 0.36 & 0.18 & 0.04 & \\
\hline & INT with high SCC in phase 3 & 0.36 & 0.15 & 0.01 & \\
\hline & INT with low SCC in phase 1 & 0.19 & 0.11 & 0.08 & \\
\hline & INT with low SCC in phase 2 & 0.08 & 0.11 & 0.49 & \\
\hline & NC with high SCC in phase 1 & 0.37 & 0.12 & 0.002 & \\
\hline & NC with high SCC in phase 2 & 0.18 & 0.11 & 0.12 & \\
\hline
\end{tabular}

${ }^{1}$ Study arms with intervention.

${ }^{2}$ Negative control study arm

${ }^{3} 6-0$ mo before report.

${ }^{4} 1-4$ mo after report.

${ }^{5} 5-12$ mo after report.

${ }^{6}$ Staphylococcus aureus genotype B. 
Table 12. Covariates associated with the annual herd-level proportion of new infections in a population-averaged linear regression model correcting for clustering at the herd level

\begin{tabular}{|c|c|c|c|c|c|}
\hline Variable & Category & Estimate & $\mathrm{SE}$ & $P$-value & $\begin{array}{l}\text { Overall } \\
P \text {-value }\end{array}$ \\
\hline Intercept & & 11.31 & 0.44 & & \\
\hline 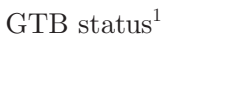 & $\begin{array}{l}\text { Bulk milk positive, participation in GTB control program } \\
\text { Bulk milk positive, no participation in GTB control program } \\
\text { Bulk milk negative }\end{array}$ & $\begin{array}{c}2.82 \\
0.55 \\
\text { Reference }\end{array}$ & $\begin{array}{l}0.44 \\
1.44 \\
-\end{array}$ & $\begin{array}{c}<0.001 \\
0.70\end{array}$ & $<0.001$ \\
\hline
\end{tabular}

${ }^{1}$ Staphylococcus aureus genotype B.

of the present study, the reason for this difference is unclear but several explanations are possible. Farmers have been reported to have different learning styles (Lam et al., 2011), which may explain why aligning udder health-improvement strategies with farmer preference was associated with a greater compliance. As all farmers of the PC, VET, and SG study arms received herd-specific recommendations, the improved compliance may also have been caused by the additional support or the social interaction involved (PC study arm: no personal interaction; VET study arm: one-to-one interaction with their own veterinarian; SG study arm: interaction with a group composed of peers, members of the project team, and a moderator). Farmer preference for a social interaction style may have influenced their willingness to accept and implement proposed management changes. As a qualitative study by Jansen et al. (2010c) showed, farmers differ in their openness toward information from the external world and their trust in external information sources. This may also explain why aligning udder health-improvement strategies to farmer preference was associated with greater compliance. Further research in this field may benefit from knowledge obtained from studies on interprofes-

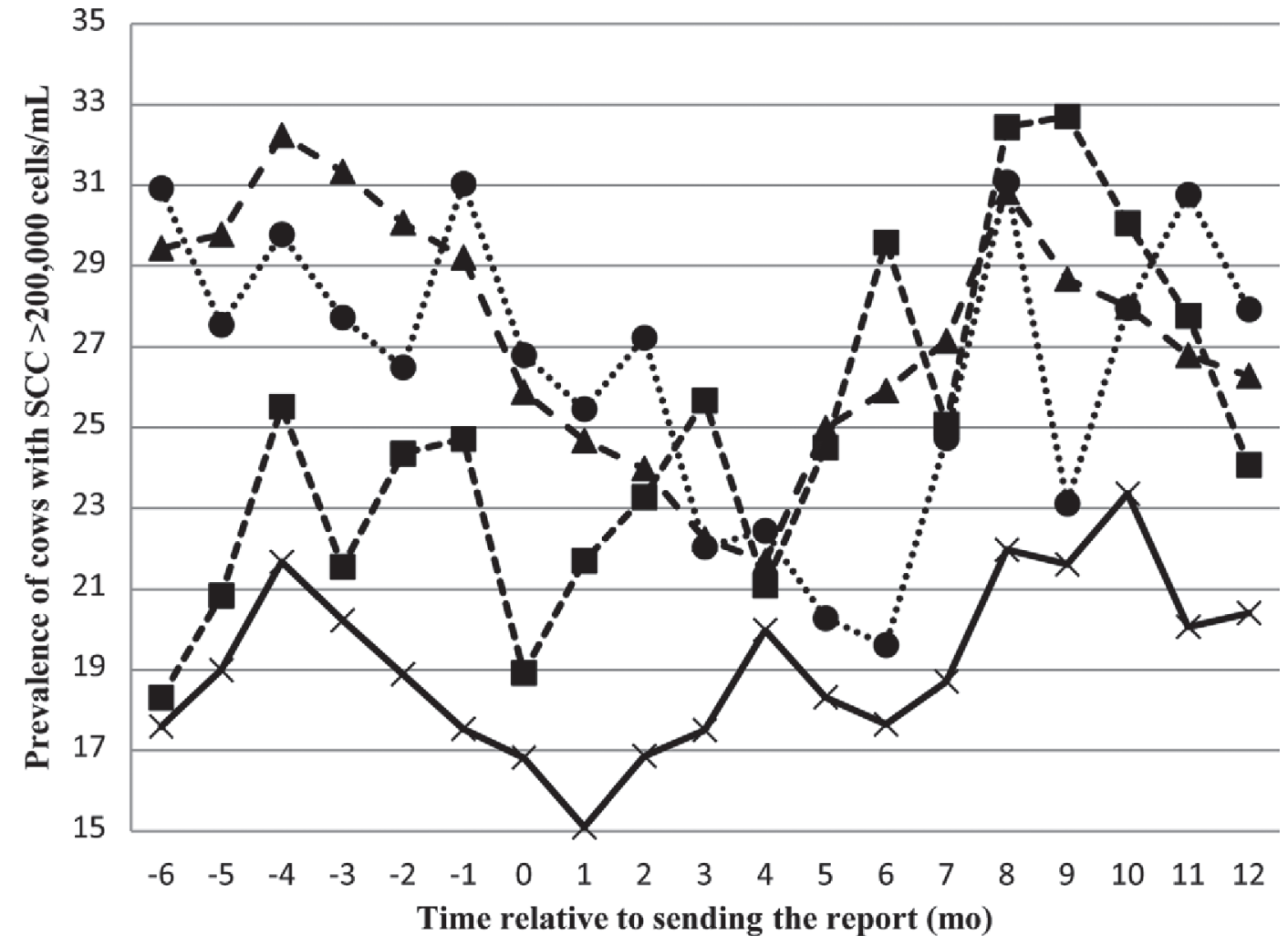

Figure 2. Observed within-herd prevalence of cows with a composite SCC $\geq 200,000$ cells/mL relative to the moment of sending the report (mo 0) in herds in the negative control study arm with a high yield-corrected bulk milk somatic cell count $(\mathrm{YCBMSCC} ; \boldsymbol{\bullet} ; \mathrm{n}=15)$ and with a low YCBMSCC $(\mathbf{\square} ; \mathrm{n}=10)$ at mo 0 as well as in herds from the study arms with an udder health improvement strategy with a high YCBMSCC $(\mathbf{\Delta} ; \mathrm{n}=43)$ and with a low $\mathrm{YCBMSCC}(\mathrm{X} ; \mathrm{n}=31)$ at mo 0. 


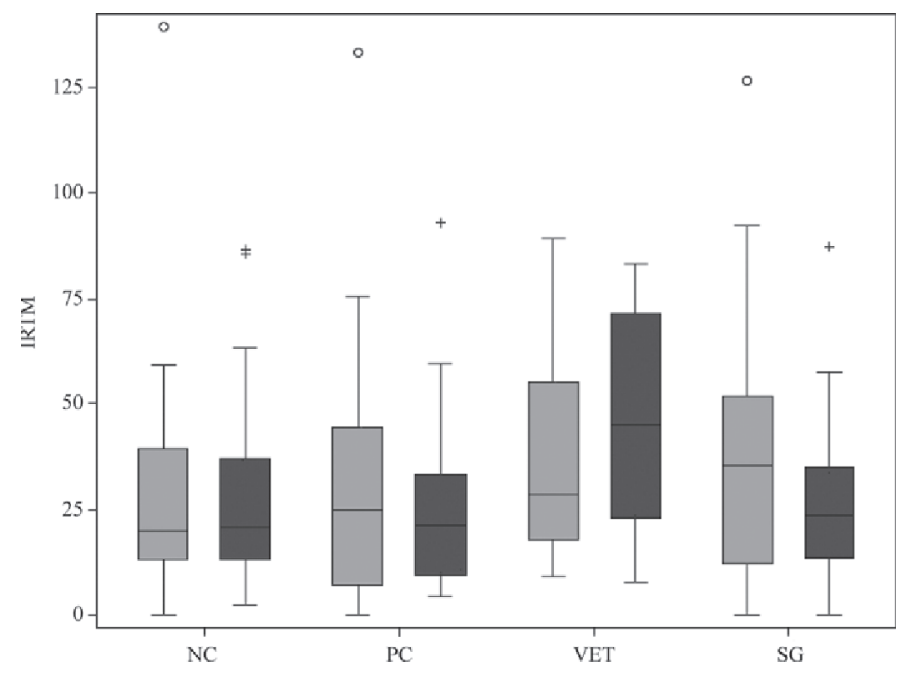

Figure 3. Boxplots of the incidence rate of treated mastitis (IRTM) in the year before (gray) and in the year after sending the advice report (black) in the negative control study arm (NC), the positive control study arm (PC), the veterinary support study arm (VET), and the study group study arm (SG). Whiskers indicate the 1.5 interquartile range; symbols represent outliers.

sional learning (Barr et al., 2005) that were conducted in the field of medical care and leaning theories in general (Driscoll, 2005; Ormrod, 2012), including aspects such as social learning and self-efficacy (Bandura, 1977; 1986). The fact that personal preferences for support strategies or interaction styles influence compliance is important to consider when designing future animal health programs.

Another reason why no reduction in the primary outcome occurred may have been the poor motivation of farmers toward mastitis control. Recent studies in
The Netherlands have shown that farmer motivation toward mastitis and mastitis management is important to consider when planning to improve udder health (Jansen et al., 2009, 2010b; Lam et al., 2011, 2013; van den Borne et al., 2014). The awareness of having an udder health problem and having confidence in the effectiveness of mastitis management strategies are key elements in farmer decisions to change their mastitis management (Janz and Becker, 1984; Jansen and Lam, 2012). Herds with a high YCBMSCC status at mo 0 had a high YCBMSCC since 2010. These farmers may not have been aware that they had a mastitis problem, they may not have had confidence in the effectiveness of the recommendations given, or they may not have had a motivation to improve. Similar observations have been done for lameness in UK dairy herds previously (Leach et al., 2013).

The present study prevented an increase in PREV in herds with a low YCBMSCC at mo 0 whereas no effect in herds with a high YCBMSCC at mo 0 could be observed. The observed effects in the herds with a low YCBMSCC at mo 0 should be interpreted with caution though, as they were based on a low number of $\mathrm{NC}$ dairy herds $(\mathrm{n}=10)$, of which 7 had a PREV $>35 \%$ at least once in that particular study phase ( 5 to $\geq 12 \mathrm{mo})$.

Besides the reasons previously stated, the effects in PREV in herds with a high or low YCBMSCC at mo 0 may also be explained by the milk quality payment system in Switzerland. This system consists of both a bonus and penalty system. It was established by the Swiss dairy industry to motivate dairy farmers to improve milk quality. According to Swiss legislation (Eidgenössische Departement des Innern, 2005), farmers receive a penalty when their geometric bulk milk SCC

Table 13. Covariates associated with the incidence rate of treated mastitis cases in a population-averaged negative binomial regression model correcting for clustering at the herd level

\begin{tabular}{|c|c|c|c|c|c|}
\hline Variable & Category & Estimate & $\mathrm{SE}$ & $P$-value & $\begin{array}{l}\text { Overall } \\
P \text {-value }\end{array}$ \\
\hline Intercept & & -7.33 & 0.18 & $<0.001$ & \multirow{5}{*}{$<0.001$} \\
\hline \multirow{4}{*}{ Study arm } & $\mathrm{PC}^{1}$ & 0.53 & 0.20 & 0.01 & \\
\hline & $\mathrm{VET}^{2}$ & -0.13 & 0.22 & 0.57 & \\
\hline & $\mathrm{SG}^{3}$ & -0.06 & 0.21 & 0.76 & \\
\hline & $\mathrm{NC}^{4}$ & Reference & - & - & \\
\hline \multirow[t]{2}{*}{ Year } & before mo 0 & 0.03 & 0.19 & 0.89 & \multirow[t]{2}{*}{0.89} \\
\hline & after mo 0 & Reference & - & - & \\
\hline \multirow[t]{2}{*}{ Bulk milk status } & $\geq 200,000$ cells $/ \mathrm{mL}$ & 0.26 & 0.13 & 0.04 & \multirow[t]{2}{*}{0.04} \\
\hline & $<200,000$ cells $/ \mathrm{mL}$ & Reference & - & - & \\
\hline \multicolumn{2}{|l|}{ Interaction: Study arm $\times$ year } & & & & \multirow{4}{*}{0.01} \\
\hline VET in the year before mo 0 & & -0.23 & 0.22 & 0.28 & \\
\hline $\mathrm{PC}$ in the year before mo 0 & & 0.08 & 0.28 & 0.78 & \\
\hline $\mathrm{SG}$ in the year before mo 0 & & 0.46 & 0.25 & 0.07 & \\
\hline
\end{tabular}


is $\geq 350,000$ cells $/ \mathrm{mL}$. Some milk-processing companies have set lower penalty thresholds. This is in contrast to other European countries where geometric bulk milk SCC levels must exceed 400,000 cells/mL before farmers receive a penalty. Conversely, Swiss farmers may receive a bonus when their bulk milk SCC is low. Differences between the quality payment systems of various milk-processing companies exist, but farmers generally receive a bonus if their BMSCC is $<100,000$ cells/ $\mathrm{mL}$. Although farmers are generally more sensitive to penalties than to bonuses for BMSCC (Valeeva et al., 2007; Huijps et al., 2010), financial incentives can act as an external motivator to maintain certain behaviors (McKenzie-Mohr, 2012). Farmers with herds that had low YCBMSCC at mo 0 may have been intrinsically motivated to improve their herd BMSCC status before the interventions started. They may have managed to decrease their YCBMSCC between 2010 and the start of the intervention in September 2011. Receiving an additional bonus may explain why a deterioration in PREV was prevented in herds with a low YCBMSCC at mo 0. Reasons why financial incentives did not motivate farmers with herds with high YCBMSCC at mo 0 to change are unclear. It could be speculated though that these farmers perceived that they would not benefit from the bonus or they felt that reaching such BMSCC levels were not within their management capabilities (Janz and Becker, 1984).

Another reason for the lack of reduction in PREV may be that the farmers received an indemnification for participating in the study. Their motivation to participate may have been the money paid for participation rather than improving cow udder health. Also, the study lasted for $1 \mathrm{yr}$ and a longer duration may have been necessary to detect an intervention effect. This was affirmed in a study of Swiss organic dairy herds where the intervention effect only became apparent in the second year (Ivemeyer et al., 2009); although a duration of 1 yr was sufficient to achieve an udder health improvement in the UK intervention study (Green et al., 2007).

No improvement of the annual herd-level proportion of NI was observed, either within the study arms or within the herds with a high or low YCBMSCC at mo 0 . Besides a consistently higher NI in herds participating in the additional Staph. aureus GTB-control program, the only other observed effect was a consistently higher NI in herds with a high YCBMSCC status at mo 0 compared with herds with a low YCBMSCC status. This was expected and is similar to other studies (Valde et al., 2005).

The borderline nonsignificant increase of IRTM in the VET study arm was expected, as diagnosing cows with IMI and treating them with antimicrobials was promoted in this study arm. In contrast, the observed decrease in IRTM in the SG study arm was not expected because no efforts were actively made in this direction. Furthermore, no differences in management changes, PREV, and NI were noted between the 3 study arms with intervention. Farmers have been shown to learn by sharing knowledge with peers having the same goal (Vaarst et al., 2007; Lam et al., 2011), and this could have enhanced their willingness to improve the udder health of their herds or to apply less antimicrobial treatments. The combination of publicly committing to improve udder health at the inaugural study group meeting (Lokhorst et al., 2013) and studying the topic in subsequent meetings may have improved farmers' perceived self-efficacy (i.e., an individual's belief in his or her ability to succeed in a specific behavior; Bandura, 1977). In addition, exchange of knowledge and experiences with peers with the same goal may have influenced positively their attitudes toward specific mastitis-management strategies and their individual norms for appropriate mastitis prevention behavior (Kallgren et al., 2000; Wood, 2000; Armitage and Conner, 2001). This may have improved the quality of the behavior (e.g., better coverage of teat dip, more accurately cleaning of cubicles), rather than changing the quantity of implemented recommendation changes (van den Borne et al., 2014). Organizing peer study group meetings seems to be a promising support strategy to reduce antimicrobial usage in Swiss dairy herds because SG participants managed to reduce IRTM while keeping their herd PREV levels constant.

The VET study arm did not show any udder health improvement in comparison with the 2 control study arms. It can only be speculated why such improvement was not observed, but the interest of a practicing veterinarian in a research project (Ivemeyer et al., 2008), the quality (Sorge et al., 2010), and the communication of the veterinary advice have been shown to influence farmer compliance (Derks et al., 2013a; Pothmann et al., 2014). For instance, veterinarians are not always aware of the farmer's goals (Kristensen and Enevoldsen, 2008; Derks et al., 2013b). Also, participating veterinarians may have been less motivated to comply than the farmers in our study. Farmers in the SG study arm were present at the peer study group meetings in $88.4 \%(145 / 164)$ of the cases, whereas only $50.3 \%$ $(94 / 187)$ of the cows with a subclinical Staph. aureus IMI were treated with antimicrobials in the VET study arm. Success of an udder health-improvement strategy is highly dependent on the actors' intrinsic motivation (Jansen et al., 2010a). Some veterinarians may have lacked the skills to perform herd health management in the current study possibly because of the small dairy herds and veterinary practices in mountainous regions 
(Pothmann et al., 2014) as well as the habit of practicing individual animal medicine (Vaarst et al., 2007). Veterinarians were actively supported by project members to perform herd health activities (i.e., diagnosing and treating new IMI and interpreting milk contents for improved feeding management), but it may be that they only visited the herds to execute these tasks. Further discussions about other udder health aspects may have been lacking, as stated by some farmers assigned to the VET study arm after the study.

Staphylococcus aureus is a contagious pathogen (Keefe, 2012) for which different genotype-specific transmission parameters have been estimated (Barlow et al., 2013). Different Staph. aureus genotypes were also identified in the current study. Recommendations for management improvement were given and prioritized accordingly; an additional control program was offered to Staph. aureus GTB-positive herds. This was done under the assumption that Staph. aureus GTB is a contagious Staph. aureus strain, whereas other Staph. aureus genotypes were considered less so, but still contagious. These assumptions were based on a high within-herd prevalence observed within Staph. aureus GTB-positive herds (Graber et al., 2009; Voelk et al., 2014). However, incidence rates and transmission parameters need to be interpreted to correctly evaluate the assumption of contagiousness, but were not available. Staphylococcus aureus GTB status was therefore added as a covariate to the statistical models for the 3 mastitis indicators to correct for the difference in approach to herds with a distinct Staph. aureus GTB status. The final regression models identified no differences between the Staph. aureus GTB-positive herds not participating in the additional control program and the other 2 categories of dairy herds, implying that the recommendations for improvement were similarly effective in improving udder health for the 3 herd categories. Conversely, a consistently higher PREV and NI in the herds participating in the additional control program for Staph. aureus GTB was observed compared with Staph. aureus GTB-negative herds. This might have been a motivation for the farmers to participate in this additional control program at the start of the study. Moreover, no improvement in PREV and NI could be observed within those herds, although a strong decline in the within-herd prevalence of Staph. aureus GTB was observed (data not shown). More research is needed to evaluate the effectiveness of this control program for Staph. aureus GTB on udder health improvement and the prevention of introduction of other Staph. aureus genotypes (and other pathogens causing IMI) into the herd.

Our study had some limitations that may have affected its results and generalizability. Farmers were actively recruited to participate, making the study potentially subject to selection bias. Second, several individual variables (Table 8) or combinations of management practices (Table 10) could have been associated with the different mastitis outcomes. However, these potential associations were not evaluated because initial model explorations identified many interaction terms with the biologically relevant covariates offered to the statistical models. This made model interpretation highly complex. Staphylococcus aureus GTB status was offered to the statistical models as a covariate though to correct for the different control udder healthimprovement strategies being used. Blinding could not be incorporated into the study design and this may have affected the study's scientific validity (Sargeant et al., 2009). Study actors were very heterogeneous (i.e., 100 different farmers, 23 different farm veterinarians, 5 different study veterinarians, and 5 different moderators of the study groups meetings), and not all may have had the same knowledge, interest, or motivation to improve udder health. This, however, reflects the heterogeneity present in Swiss dairy herds. The study was conducted as a randomized field trial and the observed effects therefore provide unbiased information that has value for designing strategies for udder health improvement in Swiss dairy herds. The unexpected results may be used to generate hypotheses for future studies to improve udder health in Switzerland and other countries.

\section{CONCLUSIONS}

To the best of our knowledge, ours is the first multiarm randomized field trial to simultaneously test 3 different udder health-improvement strategies in dairy herds. The study showed that improving udder health within 1 yr in Swiss dairy herds might be more challenging than initially expected. Organizing peer study group meetings for farmers seems to be a promising tool to decrease antimicrobial usage in dairy herds while keeping herd udder health status constant. Farmer preference for an udder health-improvement strategy had a positive effect on the degree of implementation of the recommendations being given and should be taken into consideration when supporting herds to improve udder health.

\section{ACKNOWLEDGMENTS}

The study was financially supported by the Federal Food Safety and Veterinary Office (Bern, Switzerland; grants 1.11.06 and 1.12.01), Arbeitsgemeinschaft Schweizerischer Rinderzüchter (Zollikofen, Switzerland), Förderverein Rindergesundheitsdienst (Lindau, 
Switzerland), Schweizerische Vereinigung für Wiederkäuermedizin, Gesellschaft Schweizer Tierärztinnen und Tierärzte (Thörishaus, Switzerland), Schweizer Bauerverband (Brugg, Switzerland), Schweizer Milchproduzenten (Bern, Switzerland), and Swissgenetics (Zollikofen, Switzerland). The authors acknowledge all farmers and their private veterinarians for participating in this study. We highly appreciate the efforts of Lukas Herzog (Berufsbildungszentrum Natur und Ernährung, Hohenrain, Switzerland), Vincent Gremaud (Institut agricole de l'État de Fribourg, Posieux, Switzerland), Murielle Tinguely (Prométerre, Lausanne, Switzerland), Jenifer van der Maas (Bildungs- und Beratungszentrum Arenenberg, Weinfelden, Switzerland), and Andreas Häberli (Inforama Rütti, Zollikofen, Switzerland) for moderating the study group meetings. Furthermore, the authors thank Martin Green (Faculty of Medicine \& Health Sciences, University of Nottingham, United Kingdom) and Anne Marike Lokhorst (Strategic Communication Group, Wageningen University, the Netherlands) for their comments on the design of the study, Isabel Lechner (Veterinary Public Health Institute, Liebefeld, Switzerland) for her assistance in the follow-up of the VET study arm, and John Berezowski (Veterinary Public Health Institute, Liebefeld, Switzerland) for commenting on a previous version of the manuscript.

\section{REFERENCES}

Adair, J. G. 1984. The Hawthorne effect: A reconsideration of the methodological artifact. J. Appl. Psychol. 69:334-345.

Armitage, C. J., and M. Conner. 2001. Efficacy of the theory of planned behaviour: A meta-analytic review. Br. J. Soc. Psychol. 40:471-499.

Bandura, A. 1977. Self-efficacy: Toward a unifying theory of behavioral change. Psychol. Rev. 84:191-215.

Bandura, A. 1986. Social Foundations of Thought and Action: A Social-Cognitive Theory. Prentice Hall, Englewood Cliffs, NJ.

Barkema, H. W., M. J. Green, A. J. Bradley, and R. N. Zadoks. 2009. Invited review: The role of contagious disease in udder health. J. Dairy Sci. 92:4717-4729. http://dx.doi.org/10.3168/jds.20092347.

Barkema, H. W., Y. H. Schukken, T. J. G. M. Lam, M. L. Beiboer, G. Benedictus, and A. Brand. 1999. Management practices associated with the incidence rate of clinical mastitis. J. Dairy Sci. 82:16431654. http://dx.doi.org/10.3168/jds.S0022-0302(99)75393-2.

Barkema, H. W., Y. H. Schukken, T. J. G. M. Lam, M. L. Beiboer, H. Wilmink, G. Benedictus, and A. Brand. 1998. Incidence of clinical mastitis in dairy herds grouped in three categories by bulk milk somatic cell counts. J. Dairy Sci. 81:411-419. http://dx.doi. org/10.3168/jds.S0022-0302(98)75591-2.

Barlow, J. W., R. N. Zadoks, and Y. H. Schukken. 2013. Effect of lactation therapy on Staphylococcus aureus transmission dynamics in two commercial dairy herds. BMC Vet. Res. 9:28.

Barr, H., D. Freeth, M. Hammick, I. Koppel, and S. Reeves. 2005. Effective Interprofessional Education: Argument, Assumption and Evidence. Blackwell Publishing, London, UK.

Bennedsgaard, T. W., I. C. Klaas, and M. Vaarst. 2010. Reducing use of antimicrobials - Experiences from an intervention study in organic dairy herds in Denmark. Livest. Sci. 131:183-192. http:// dx.doi.org/10.1016/j.livsci.2010.03.018.
Boss, R., J. Naskova, A. Steiner, and H. U. Graber. 2011. Mastitis diagnostics: Quantitative PCR for Staphylococcus aureus genotype B in bulk tank milk. J. Dairy Sci. 94:128-137. http://dx.doi. org/10.3168/jds.2010-3251.

Bradley, A. J., K. A. Leach, J. E. Breen, L. E. Green, and M. J. Green. 2007. Survey of the incidence and aetiology of mastitis on dairy farms in England and Wales. Vet. Rec. 160:253-257.

Breen, J. E., M. J. Green, and A. J. Bradley. 2009. Quarter and cow risk factors associated with the occurrence of clinical mastitis in dairy cows in the United Kingdom. J. Dairy Sci. 92:2551-2561. http://dx.doi.org/10.3168/jds.2008-1369.

Brightling, P., R. Dyson, A. Hope, and J. Penry. 2009. A national programme for mastitis control in Australia: Countdown downunder. Ir. Vet. J. 62(Suppl 4):S52-S58. http://dx.doi.org/10.1186/20460481-62-S4-S52.

de Haas, Y., R. F. Veerkamp, H. W. Barkema, Y. T. Gröhn, and Y. H. Schukken. 2004. Associations between pathogen-specific cases of clinical mastitis and somatic cell count patterns. J. Dairy Sci. 87:95-105. http://dx.doi.org/10.3168/jds.S0022-0302(04)73146-X.

Derks, M., L. M. van de Ven, T. van Werven, W. D. J. Kremer, and H. Hogeveen. 2012. The perception of veterinary herd health management by Dutch dairy farmers and its current status in the Netherlands: A survey. Prev. Vet. Med. 104:207-215. http://dx.doi. org/10.1016/j.prevetmed.2011.12.019.

Derks, M., T. van Werven, H. Hogeveen, and W. D. J. Kremer. 2013a. Veterinary herd health management programs on dairy farms in the Netherlands: Use, execution, and relations to farmer characteristics. J. Dairy Sci. 96:1623-1637. http://dx.doi.org/10.3168/ jds.2012-6106.

Derks, M., B. van Woudenbergh, M. Boender, W. D. J. Kremer, T. van Werven, and H. Hogeveen. 2013b. Veterinarian awareness of farmer goals and attitudes to herd health management in The Netherlands. Vet. J. 198:224-228. http://dx.doi.org/10.1016/j. tvjl.2013.07.018.

Driscoll, M. 2005. Psychology of Learning for Instruction. 3rd ed. Allyn and Bacon, Boston, MA.

Dufour, S., A. Fréchette, H. W. Barkema, A. Mussell, and D. T. Scholl. 2011. Invited review: Effect of udder health management practices on herd somatic cell count. J. Dairy Sci. 94:563-579. http://dx.doi.org/10.3168/jds.2010-3715.

Eidgenössische Departement des Innern (EDI). 2005. Verordnung des EDI über die Hygiene bei der Milchproduktion. Bern, Switzerland.

Eidgenössisches Volkswirtschaftsdepartement. 2006. Richtlinien über die Installation der Melkanlagen. Accessed August 2012. http:// www.slv-asma.ch/fileadmin/user_upload/slv-asma/oeffentlich/ fachgruppen/fachgruppe_d/branchenstandard/6_branchenstan dard_instrichtlinien_d.pdf.

Graber, H. U., J. Naskova, E. Studer, T. Kaufmann, M. Kirchhofer, M. Brechbühl, W. Schaeren, A. Steiner, and C. Fournier. 2009. Mastitis-related subtypes of bovine Staphylococcus aureus are characterized by different clinical properties. J. Dairy Sci. 92:1442-1451. http://dx.doi.org/10.3168/jds.2008-1430.

Green, M. J., K. A. Leach, J. E. Breen, L. E. Green, and A. J. Bradley. 2007. National intervention study of mastitis control in dairy herds in England and Wales. Vet. Rec. 160:287-293.

Halasa, T., K. Huijps, O. Østerås, and H. Hogeveen. 2007. Economic effects of bovine mastitis and mastitis management: A review. Vet. Q. 29:18-31.

Harmon, R. J. 1994. Physiology of mastitis and factors affecting somatic cell counts. J. Dairy Sci. 77:2103-2112. http://dx.doi. org/10.3168/jds.S0022-0302(94)77153-8.

Hogeveen, H., K. Huijps, and T. J. G. M. Lam. 2011. Economic aspects of mastitis: New developments. N. Z. Vet. J. 59:16-23.

Huijps, K., H. Hogeveen, T. J. G. M. Lam, and R. B. M. Huirne. 2009. Preferences of cost factors for mastitis management among Dutch dairy farmers using adaptive conjoint analysis. Prev. Vet. Med. 92:351-359. http://dx.doi.org/10.1016/j.prevetmed.2009.08.024.

Huijps, K., H. Hogeveen, T. J. G. M. Lam, and A. G. Oude Lansink. 2010. Costs and efficacy of management measures to improve udder health on Dutch dairy farms. J. Dairy Sci. 93:115-124. http://dx.doi.org/10.3168/jds.2009-2412. 
Ivemeyer, S., A. Maeschli, M. Walkenhorst, P. Klocke, F. Heil, S. Oser, and C. Notz. 2008. Effects of a two-year dairy herd health management program on udder health, use of antibiotics and longevity. Schweiz. Arch. Tierheilkd. 150:499-505.

Ivemeyer, S., M. Walkenhorst, F. Heil, C. Notz, A. Maeschli, G. Butler, and P. Klocke. 2009. Management factors affecting udder health and effects of a one year extension program in organic dairy herds. Animal 3:1596-1604. http://dx.doi.org/10.1017/ S1751731109990498.

Jansen, J., and T. J. G. M. Lam. 2012. The role of communication in improving udder health. Vet. Clin. North Am. Food Anim. Pract. 28:363-379.

Jansen, J., R. J. Renes, and T. J. G. M. Lam. 2010a. Evaluation of two communication strategies to improve udder health management. J. Dairy Sci. 93:604-612. http://dx.doi.org/10.3168/ jds.2009-2531.

Jansen, J., C. D. M. Steuten, R. J. Renes, N. Aarts, and T. J. G. M. Lam. 2010c. Debunking the myth of the hard-to-reach farmer: Effective communication on udder health. J. Dairy Sci. 93:12961306. http://dx.doi.org/10.3168/jds.2009-2794.

Jansen, J., B. H. P. van den Borne, R. J. Renes, G. van Schaik, T. J. G. M. Lam, and C. Leeuwis. 2009. Explaining mastitis incidence in Dutch dairy farming: The influence of farmers' attitudes and behaviour. Prev. Vet. Med. 92:210-223. http://dx.doi. org/10.1016/j.prevetmed.2009.08.015.

Jansen, J., G. van Schaik, R. J. Renes, and T. J. G. M. Lam. 2010b. The effect of a national mastitis control program on the attitudes, knowledge, and behavior of farmers in the Netherlands. J. Dairy Sci. 93:5737-5747. http://dx.doi.org/10.3168/jds.2010-3318.

Janz, N. K., and M. H. Becker. 1984. The health belief model: A decade later. Health Educ. Q. 11:1-47.

Kallgren, C. A., R. R. Reno, and R. B. Cialdini. 2000. A focus theory of normative conduct: When norms do and do not affect behavior. Pers. Soc. Psychol. Bull. 26:1002-1012. http://dx.doi. org $/ 10.1177 / 01461672002610009$.

Keefe, G. 2012. An update on control of Staphylococcus aureus and Streptococcus agalactiae for management of mastitis. Vet. Clin. North Am. Food Anim. Pract. 28:203-216.

Kretzschmar, L., B. H. P. van den Borne, T. Kaufmann, M. Reist, D. Strabel, M. Harisberger, A. Steiner, and M. Bodmer. 2013. Mastitis-management in Schweizer Milchviehbetrieben mit Eutergesundheitsproblemen. Schweiz. Arch. Tierheilkd. 155:453-462. http:// dx.doi.org/10.1024/0036-7281/a000491/.

Kristensen, E., and C. Enevoldsen. 2008. A mixed methods inquiry: How dairy farmers perceive the value(s) of their involvement in an intensive dairy herd health management program. Acta Vet. Scand. 50:50. http://dx.doi.org/10.1186/1751-0147-50-50.

Lam, T. J. G. M., J. Jansen, B. H. P. van den Borne, R. J. Renes, and H. Hogeveen. 2011. What veterinarians need to know about communication to optimise their role as advisors on udder health in dairy herds. N. Z. Vet. J. 59:8-15.

Lam, T. J. G. M., B. H. P. van den Borne, J. Jansen, K. Huijps, J. C. L. van Veersen, G. van Schaik, and H. Hogeveen. 2013. Improving bovine udder health: A national mastitis control program in the Netherlands. J. Dairy Sci. 96:1301-1311. http://dx.doi. org/10.3168/jds.2012-5958.

Lavori, P. W., and J. Kelsey. 2002. Introduction and overview. Epidemiol. Rev. 24:18-20.

Leach, K. A., E. S. Paul, H. R. Whay, Z. E. Barker, C. M. Maggs, A. K. Sedgwick, and D. C. J. Main. 2013. Reducing lameness in dairy herds - Overcoming some barriers. Res. Vet. Sci. 94:820-825.

LeBlanc, S. J., K. D. Lissemore, D. F. Kelton, T. F. Duffield, and K. E. Leslie. 2006. Major advances in disease prevention in dairy cattle. J. Dairy Sci. 89:1267-1279. http://dx.doi.org/10.3168/jds. S0022-0302(06)72195-6.

Lievaart, J. J., W. D. J. Kremer, and H. W. Barkema. 2007. Short communication: Comparison of bulk milk, yield-corrected, and av- erage somatic cell counts as parameters to summarize the subclinical mastitis situation in a dairy herd. J. Dairy Sci. 90:4145-4148. http://dx.doi.org/10.3168/jds.2006-871.

Lokhorst, A. M., C. Werner, H. Staats, E. van Dijk, and J. L. Gale. 2013. Commitment and behavior change: A meta-analysis and critical review of commitment-making strategies in environmental research. Environ. Behav. 45:3-34. http://dx.doi. org $/ 10.1177 / 0013916511411477$.

Main, D. C. J., K. A. Leach, Z. E. Barker, A. K. Sedgwick, C. M. Maggs, N. J. Bell, and H. R. Whay. 2012. Evaluating an intervention to reduce lameness in dairy cattle. J. Dairy Sci. 95:29462954

McKenzie-Mohr, D. 2012. Fostering Sustainable Behavior. 3rd ed. New Society Publisher, Gabriola Island, Canada.

NMC. 1999. Laboratory Handbook on Bovine Mastitis. Rev. ed. National Mastitis Council, editor. Madison, WI

Ormrod, J. 2012. Human Learning. 6th ed. Pearson, Boston, MA.

Pothmann, H., K. Nechanitzky, F. Sturmlechner, and M. Drillich. 2014. Consultancy to dairy farmers relating to animal health and herd health management on small- and medium-sized farms. J. Dairy Sci. 97:851-860. http://dx.doi.org/10.3168/jds.2013-7364.

Sanford, C. J., G. P. Keefe, J. Sanchez, R. T. Dingwell, H. W. Barkema, K. E. Leslie, and I. R. Dohoo. 2006. Test characteristics from latent-class models of the California Mastitis Test. Prev. Vet. Med. 77:96-108. http://dx.doi.org/10.1016/j.prevetmed.2006.06.006.

Sargeant, J. M., R. Elgie, J. Valcour, J. Saint-Onge, A. Thompson, P. Marcynuk, and K. Snedeker. 2009. Methodological quality and completeness of reporting in clinical trials conducted in livestock species. Prev. Vet. Med. 91:107-115. http://dx.doi.org/10.1016/j. prevetmed.2009.06.002.

Sorge, U., D. Kelton, K. D. Lissemore, A. Godkin, S. Hendrick, and S Wells. 2010. Attitudes of Canadian dairy farmers toward a voluntary Johne's disease control program. J. Dairy Sci. 93:1491-1499. http://dx.doi.org/10.3168/jds.2009-2447.

Syring, C., R. Boss, M. Reist, M. Bodmer, J. Hummerjohann, P. Gehrig, and H. U. Graber. 2012. Bovine mastitis: The diagnostic properties of a PCR-based assay to monitor the Staphylococcus aureus genotype B status of a herd, using bulk tank milk. J. Dairy Sci. 95:3674-3682. http://dx.doi.org/10.3168/jds.2011-4968.

Vaarst, M., T. B. Nissen, S. Østergaard, I. C. Klaas, T. W. Bennedsgaard, and J. Christensen. 2007. Danish stable schools for experiential common learning in groups of organic dairy farmers. J. Dairy Sci. 90:2543-2554. http://dx.doi.org/10.3168/jds.2006-607.

Valde, J. P., O. Østerås, and E. Simensen. 2005. Description of herd level criteria for good and poor udder health in Norwegian dairy cows. J. Dairy Sci. 88:86-92. http://dx.doi.org/10.3168/jds. S0022-0302(05)72665-5.

Valeeva, N. I., T. J. G. M. Lam, and H. Hogeveen. 2007. Motivation of dairy farmers to improve mastitis management. J. Dairy Sci. 90:4466-4477. http://dx.doi.org/10.3168/jds.2007-0095.

van den Borne, B. H. P., J. Jansen, T. J. G. M. Lam, and G. van Schaik. 2014. Associations between the decrease in bovine clinical mastitis and changes in dairy farmers' attitude, knowledge and behavior in the Netherlands. Res. Vet. Sci. 97:226-229. http:// dx.doi.org/10.1016/j.rvsc.2014.06.017.

van den Borne, B. H. P., G. van Schaik, T. J. G. M. Lam, and M. Nielen. 2010. Variation in herd level mastitis indicators between primi- and multiparae in Dutch dairy herds. Prev. Vet. Med. 96:49-55. http://dx.doi.org/10.1016/j.prevetmed.2010.05.010.

Voelk, V., H. U. Graber, B. H. P. van den Borne, C. Sartori, A. Steiner, M. Bodmer, and M. C. Haerdi-Landerer. 2014. A longitudinal study investigating the prevalence of Staphylococcus aureus genotype B in seasonally communal dairy herds. J. Dairy Sci. 97:4184-4192. http://dx.doi.org/10.3168/jds.2013-7291.

Wood, W. 2000. Attitude change: persuasion and social influence. Annu. Rev. Psychol. 51:539-570. http://dx.doi.org/10.1146/annurev.psych.51.1.539. 